\title{
Judicial tyranny or American justice? How partisan news' coverage of polarizing Supreme Court decisions differs in framing the nation's highest court
}

\author{
Lisa Matthias* \\ Germany \\ *Corresponding author's e-mail address: I.a.matthia@gmail.com \\ Published online: 15 September 2016 (Version 1) \\ referee's comments please click here or scan the QR code at the end of this article. \\ Primary Discipline: Political science \\ Secondary Discipline: Communication \& Media studies \\ Keywords: framing, partisan news, Supreme Court, fox news, MSNBC, polarization
}

John F. Kennedy Institute for North American Studies, Department of Political Science, Freie Universität Berlin, Berlin,

Cite as: L. Matthias. ScienceOpen Research 2016 (DOI: 10.14293/S2199-1006.1.SOR-SOCSCI.AYUSLA.v1)

Reviewing status: Please note that this article is under continuous review. For the current reviewing status and the latest

\begin{abstract}
The U.S. Supreme Court is isolated from the public, yet dependent on high levels of public support to maintain its legitimacy. Due to its distance, the media has great control over how the nation's highest court is presented to the public. Partisan news outlets cater their stories to audiences with distinct ideological beliefs, reinforcing them while opposing opposite beliefs. This can lead to partisan polarization, which has previously been exclusive to the political realm. However, recent polls have revealed an existing party gap in the Supreme Court's level of public support, which implies a politicization of the judiciary branch. When the Supreme Court appears to be just another political institution or simply an extension of the other two governmental branches, its integrity is greatly impaired, and, as a consequence, the public's confidence in the Justices is likely to deteriorate. This study analyzes Fox News' and MSNBC's news coverage of two pollogical stance aligns with the Court's decision, the Supreme Court is presented as an apolitical institution, whereas it is politicized when the decision is contrary the channel's partisan stance. This implies that the partisan divide, once only common to the political realm has now reached the judiciary.
\end{abstract}

\section{INTRODUCTION}

"Judicial tyranny" (Kelly, 2015, p. 2) or "American justice" (Maddow, 2015, p. 3)? These two, vastly divergent evaluations illustrate the asymmetrical nature of the partisan news' coverage of Supreme Court decisions that seemingly divide the Justices along the partisan line. As news outlets that clearly position themselves on different poles ${ }^{1}$ on the ideological scale, Fox News and MSNBC reinforce their audiences' ideological views by framing their reports accordingly. Moreover, news framing can affect the public's understanding and evaluation of events and actors. Considering that the Supreme Court is isolated from the public, yet dependent on high levels of public support, it follows that the media's framing of the judiciary is crucial for the Court to maintain its legitimacy. Hence, the present study explores how partisan outlets, Fox News and MSNBC in particular, frame the Supreme Court.

The current state of the American news media landscape can be described with one word: change. First of all, newspaper readership has been declining for several years, and with advancing technology, television and online news has become more popular. Second, the speed with which information can be disseminated has increased dramatically, and with the advent of 24-hour news channels, such as Fox News and MSNBC, it became possible for the media to react to current events almost immediately, without having to interrupt the usual program. Third, viewers are now offered an abundance of choice of TV channels, and therefore they have greater control over the shaping of their media consumption (Prior, 2005, 2007; Sunstein, 2001). On the one hand, this means that following the news has become a conscious choice because there is a great array of alternative programs. On the other hand, this also provides the politically interested the opportunity to

\footnotetext{
1. Describing Fox News and MSNBC as different poles on the ideological scale should not be interpreted as defining both outlets as binary opposites; rather, this serves as a means to emphasize their conflicting positions.
} 
select what kind of political views they want to encounter while watching the news and which ones they want to mute. These channels that cater to distinct audiences with distinct ideological views are referred to as partisan channels. These outlets create a strong sense of community for their audience by treating in-group members far more positively than outgroup members. In contrast to favorable views, opposing ones are generally marginalized and presented as alien and incompatible with the target audience's views. Thus, opposing views are strongly criticized or even attacked, whereas the audience's own ideological stance is defended and reinforced. Being constantly exposed to one-sided news coverage that bolsters personally held beliefs can also encourage the public to form more radicalized and polarized opinions. This attitude polarization can possibly lead to far-reaching derogatory consequences for a well-functioning democratic system, such as decreasing trust in the opposition. With regard to the recent event of Antonio Scalia's death and the ongoing appointment process of his successor, it becomes obvious that this polarization can also affect the Supreme Court. To briefly explain, according to Article 2 of the U.S. Constitution to appoint a federal judge the President nominates a candidate with the advice and consent of the Senate. Then, the Senate Judicial Committee holds a hearing to assess the candidate's suitability and votes once the hearing has been performed. If there are no objections to the nominee's character or qualifications, that person is confirmed within only a short time. However, the recent nomination of Merrick Garland is quite different. Since the Senate, currently dominated by the Republican Party, refuses even to hold hearings for any candidate proposed by President Obama (Yuhas \& Helmore, 2016), Garland's appointment process has lasted for 4 months up until now. This current issue indicates that the partisan polarization, which once was only common to the political sphere, has now reached the judiciary branch as well.

As a consequence, the public's evaluation of the Supreme Court has become increasingly influenced by their partisan stance (Drake, 2016; Jones, 2015). The distance the Court keeps to the media is meant to encourage viewing the institution as distinctively different from the other two branches of government, yet this distance also entails that the media has great control over how the Court is presented to the public. As already mentioned, partisan news outlets cover politically laden issues from different ideological perspectives. The technique, which is used to communicate the channels' messages, is referred to as framing. To put it simply, framing augments certain aspects of a story by increasing their salience, while it omits others, in order "to promote a particular interpretation, evaluation, and/or solution" (Entman, 2003). As previous studies have shown, framing can affect how the public understands certain issues (Pan, Meng, \& Zhou, 2010) and how it evaluates political actors or institutions (Carlin \& Winfrey, 2009). Thus, news frames can provide valuable information about what it is exactly that distinguishes one partisan channel from another and by what means these outlets communicate their distinct views.

Despite the gtring body of framing research, little has been done that explicitly explores how the Supreme Court is presented by partisan channels or the media in general. Previous research has mostly focused on how the public actually perceives the Court (Scheb \& Lyons, 2001), how symbols of judicial authority in news reports affect public support after controversial decisions (Gibson et al., 2010), and how the media frames particular Supreme Court nominees or decisions (Gibson \& Caldeira, 2009). Considering that the Court is exceptionally dependent on high levels of public support, and since the media provides most of the information the public uses to form an opinion about the Court, it is of concern to shift the focus in framing research from how the media can possibly influence public support for the Court to how the Court is actually represented by the media. Given the existing party gap in levels of support for the Supreme Court (McCarthy, 2015), this new focus gives special importance to partisan channels and raises the question if these outlets present the Court as politicized. Hence, the purpose of this qualitative study is to analyze how Fox News and MSNBC frame the U.S. Supreme Court. Revealing in how far channels with opposing ideological views differ in framing the Supreme Court could offer an explanation for the divergent levels of public support. Moreover, this study adds to the alreadyexisting knowledge of news framing as a means to communicate and reinforce ideological beliefs and sheds light on how partisan channels politicize the nation's highest court.

When the Supreme Court appears to be just another political institution or simply an extension of the other two governmental branches, its integrity is greatly impaired, and, as a consequence, the public's confidence in the Justices to make fair and impartial decisions is likely to deteriorate. Yet, public confidence is fundamental for the Court to function properly, given that a dramatic decline in public support could result in the non-implementation of its rulings, which would undermine its legitimacy. As a consequence, the Justices could become inclined to decide in favor of the dominant political party to restore their legitimacy and functionality. The media's power to shape the public's understanding of democratic institutions and the fact that public disapproval of the high Court has risen to a 30-year record high (Drake, 2016; McCarthy, 2015), once again underline the importance of understanding how the media in general and partisan news in particular frame the Supreme Court.

For the purpose of contributing to a better understanding of the divergent nature of partisan news, the present study analyzes Fox News's and MSNBC's evening news coverage following the Supreme Court decisions in Burwell v. Hobby Lobby and Obergefell $v$. Hodges and addresses the following primary research question: How do Fox News and MSNBC frame the Supreme Court when its decision does or does not reflect the channels' ideological beliefs? To support and 
enhance those findings, the distribution of contributors during the coverage and the terminology used to refer to the Supreme Court are analyzed subsequently. First, a qualitative frame analysis is conducted in order to reconstruct the channels' narratives. Since only few studies have explored the Supreme Court's representation in the news, the transcripts are coded through an inductive approach, which does not limit the analysis to previously defined categories but allows for the frames to emerge from the material. Subsequent to identifying the frames, the transcripts are quantitatively coded to determine the channels' contributor and terminology patterns, which provide further insight into the channels' framing strategies.

The present study rests on three basic assumptions. First, the media has the power to affect the public's understanding and perception of events and actors. This assumption is based on the premise that although the media does not tell the audience what to think directly, it suggests what to think about by highlighting specific aspects of a story and, thereby, ascribing greater importance to those elements. Hence, those aspects become more salient, which means that the audience is more likely to accept and consider them. Second, it is assumed that partisan news channels reflect their target audience's ideology. This assumption rests on the premise that all news outlets face the issue of audience competition and, as a means to address that problem, partisan channels shape their programs in a way that attracts an audience with specific ideological perspectives. Third, it is assumed that ideological beliefs and party identification are closely connected. This assumption is based on polls that show that Republicans mostly identify themselves as conservatives, whereas Democrats refer to themselves as liberals ("Political Polarization in the American Public," 2014).

Still, the present study is limited in its scope. On the one hand, the sample size is relatively small considering that it only includes the transcripts of two partisan channels' coverage of two Supreme Court decisions. On the other hand, qualitative research methods raise the issues of replicability and objectivity. Nevertheless, a qualitative approach allows for an indepth analysis, which is especially valuable for research on topics only little attention has been devoted to yet. The study's limitations are addressed again and further explained in Chapter 3.

The present study understands partisan channels to be outlets that reinforce a particular ideological perspective through slanted $^{2}$ reports (Levendusky, 2013a,b), and, accordingly, Fox News and MSNBC can be defined as such (Chalif, 2011). Ideology is considered to be a system of distinct values and views, which provides specific means to make sense of the world (Eagleton, 1991). With regard to Fox News and MSNBC, previous research has shown that the channels represent

\footnotetext{
2. Entman (2007) defines slant as "framing [that] favors one side over the other in a current or potential issue."
}

conservative and liberal ideological values, respectively. To briefly explain in how far both ideologies are different from each other, it is useful to look at their core values. In general, liberals value empathy, need-based fairness, and a government that protects its people equally, whereas conservatives attribute more importance to discipline, self-reliance, and individual responsibility (Lakoff, 2006).

\section{PARTISAN MEDIA}

With the advent of cable television, the American media landscape began to offer a broad variety of TV channels, including news channels that cater to specific partisan groups. As Mutz (2006) argues, the availability of partisan news channels should encourage selective exposure (Hollander, 2008; Stroud, 2008) because audience members can find news programs that are compatible with their views more easily. Consequently, viewers that identify themselves as conservative and/or Republican are more likely to choose conservative outlets, such as Fox News, while blocking out more liberal channels like MSNBC (Stroud, 2007). The same would be true in reverse (Stroud, 2007). Although the present study does not examine possible effects that partisan news might have on the American public, these effects are the reason for why it is important to analyze which strategies are used by those outlets. Hence, they are addressed briefly. Partisan news channels constantly reinforce and strengthen their target audience's political beliefs, while adopting a hostile position toward opposing views at the same time. As previous studies have revealed, further fragmentation of the U.S. media landscape can lead to further polarization and radicalization of the two ideological views (Holbert, Garrett, \& Gleason, 2010, Jamieson \& Cappella, 2008, Stroud, 2010; Sunstein, 2009a). As a consequence, it is possible that trust in the opposition decreases and, therefore, reluctance to compromise increases (Morris, 2007), which could ultimately result in decreasing support for bipartisanship altogether (Chalif, 2011; Jamieson \& Capella, 2008, Levendusky, 2013b, Morris \& Francia, 2010; Smith \& Searles, 2012).

These effects can have a tremendous impact on American politics, yet some scholars question the actual impact of partisan channels. On the one hand, the American media landscape offers an abundance of program choices nowadays (Arceneaux \& Johnson, 2013), which means that it is possible to tune out of news programs altogether and resort to entertainment channels instead. Three decades ago, the media offered only limited choices and news were consumed by default but due to the emergence of a high-choice media system, watching the news has become a conscious choice. In addition, this proliferation of alternatives also means that when choosing to watch the news, viewers can tailor their experience exactly to their preferences (Prior, 2005; Sunstein, 2001, 2009b). For one, this translates into the choice between partisan and network news. As statistics show, partisan channels have far smaller audiences compared to network news (Holcomb 2016, Matsa 2016), which is another reason 
to question the gravity of their impact. Yet, partisan channels reported a recent increase in viewership numbers (Holcomb 2016, Matsa 2016). Moreover, it has also been shown that their viewers are politically active and more influential as compared to other groups within American society (Arceneaux \& Johnson, 2013; Bai, 2009; Jamieson \& Cappella, 2008; Levendusky, 2013a,b; Prior 2013; Holcomb 2016). Generally speaking, the importance of partisan channels rests on the fact that they are part of the American media system and, thus, contribute to shaping public discourse. But how exactly do partisan channels communicate their views? Partisan channels typically broadcast one-sided coverage that reinforces their target audience's political beliefs (Aday, 2010; Aday, Livingston, \& Hebert, 2005; Chalif, 2011; Jamieson \& Cappella, 2008; Levendusky, 2013a,b; Smith \& Searles, 2012). In addition, they create a sense of community for their viewers by treating in-group members favorably, while marginalizing out-group members and presenting them as threatening and erroneous (Jamieson \& Cappella, 2008). One way to achieve this divergent perception is to alter the groups' visibility by dedicating unequal broadcast time to them. This is what Morris and Francia's (2010) study on media bias in the coverage of the National Party Convention 2004 found. The study's results show that by giving Republican candidates more airtime than their Democratic counterparts, Fox News grants the Republican Party a greater opportunity to present themselves. However, it can be just as damaging for candidates to receive publicity from partisan channels. As Smith's (2012) analysis of Fox News's and MSNBC's programs ${ }^{3}$ during the 2008 presidential elections reveals, both channels in fact set the primary focus on the candidate opposite to their audiences' political stance. Yet, those segments serve to attack the candidates as well as to present their views as alien and unreasonable. Another example is the coverage of John Kerry's presidential campaign; conservative news outlets used four specific methods to disparage the candidate: "extreme hypotheticals, ridicule, challenges to character, and association with strong negative emotion" (Jamieson \& Cappella, 2008, p. 6). Hence, opposing views do in fact find their way into partisan programs. However when they do, they are strongly criticized and used to defend and reinforce the audience's political stance. In contrast, the general coverage is more affirmative and a more positive tone is used when partisan channels cover candidates, whose ideology and party coincide with their audiences' preferences (Morris \& Francia, 2010). Therefore, it can be claimed that the audiences' own views are augmented while counterarguments are not presented in a fair or balanced manner. This is an important point because of the tendency to dismiss information that challenges personal

\footnotetext{
3. Smith also differentiates between straight and opinion news shows, but since the present study is not concerned with different types of news shows, these differences are not elaborated.
}

beliefs (Taber, Cann, \& Kucsova, 2008; Taber \& Lodge, 2006). Those beliefs appear even more reasonable and are more easily accepted when counterarguments are not presented in a convincing way. To give an example, a content analysis of reports on global warming on CNN, MSNBC, and Fox News reveals that Fox News employed a more dismissive tone in those segments. In addition, Fox News included more voices that doubt global warming and the channel's viewers were also more likely to question the existence of global warming as compared to the other channels (Feldman, Maibach, RoserRenouf, \& Leisetritz, 2011).

To sum up, partisan channels use strategies, such as source selection and tone, to present one-sided accounts that reinforce their audiences' viewpoints while marginalizing opposing views.

\section{FRAMING}

Another strategy that partisan outlets use to convey their messages is framing. Framing was first understood in a sociological context referring to interpretative schemes that allow individuals or groups to make sense of their everyday world and experiences (Goffman, 1974). Frames facilitate efficient, cognitive processing of new information by categorizing it into preexisting groups, instead of treating it as something entirely unfamiliar. Frames are present throughout the media's entire communicative process: journalists use them to structure news texts, their sources employ frames to communicate their message effectively, and the audience uses frames to process the information presented to them. Framing can be defined as "selecting and highlighting some facets of events or issues, and making connections among them so as to promote a particular interpretation, evaluation, and/or solution" (Entman, 2003).

However, it is crucial to understand that frames differ from other forms of communication. First, frames are not topics. Topics refer to what a news story is about, whereas frames focus on how that story is told. For instance, a news report could be about the Supreme Court's ruling legalizing same-sex marriage nationwide. This would be the topic of the report. Yet, there are different ways of presenting, that is, framing, the ruling. The report could, for instance, describe the decision in terms of equality, morality, or conflict. Second, frames are diachronic (Entman, 2010). To explain, at a given point in time (Time 0 ) a certain set of schemas is dominant in a society. Then, an incident occurs at Time 1, to which the media responds by reporting the event at Time 2 . The public reacts to the media's reports at Time 3 . At Time 4 , the media can respond to the public's reaction with updated frames. ${ }^{4}$ It should be noted, however, that these different points in time can overlap or even occur simultaneously. Finally, successful

\footnotetext{
4. This is a highly simplified version of Entman's (2010) description of the diachronic process, which thoroughly explains how different actors on different levels of the communicative process construct and respond to frames.
} 
frames employ cultural resonance and magnitude, which means that frames are used repetitively and contain symbols and wordings especially noticeable within their given cultural context (Entman, 2003).

There are two different kinds of frames: procedural and substantive. Procedural frames concern the evaluation of political actors and can be applied to the political process. The most common examples are the game frame and the horserace frame, which are frequently used during elections. Substantive frames can set their focus on an actor, an issue, or an event. Moreover, they fulfill at least two of the following functions: defining an issue as problematic, identifying their causes, expressing moral judgment, and suggesting solutions (Entman, 1993; Gamson, 1992). An example would be portraying the Supreme Court's decision-making process as flawed (problem) because the Justices did not follow legal principles, but personal interests to reach a verdict. Consequently, the Court would be evaluated as politicized and a proposed remedy could be to restrict the Court's power. So, how do media frames work? The goal of media framing is to promote a certain interpretation of facts. For this purpose, framing devices such as metaphors, key terms, symbols, concepts, and source selection are used to put forth the message (De Vreese, 2005; Entman, 1993, Kuypers, 2010). Further, framing involves selecting certain elements of a story and making them more salient while neglecting others. Elevated salience means that those aspects are more noticeable for the audience and easier to memorize (Fiske \& Taylor, 1991). This point is of particular importance with regard to partisan media because the audiences' positions are reinforced as attention is drawn to particular aspects that reflect the viewers' viewpoints. Simultaneously, instances that challenge the audiences' beliefs are dismissed, which elevates the prominence of advocated beliefs.

Hence, framing can be used as a tool to shape news reports by either augmenting or neglecting certain elements. Consequently, the person who uses a frame deserves special attention. Entman's (2003) model of cascading activation helps to explain how frames spread through society. As the metaphor implies, different levels are involved in this process, and each adds a particular twist to the message. Further, it is easier for frames, which originated at the top level, to be disseminated downward than it is for frames spreading upward. The administration is situated at the top level, which is followed by non-administrative elites, such as Congress members and experts. The next stages are the media, the frames within news reports, and, finally, the public. Entman's model is especially helpful to understand patterns of source selection. Accordingly, those who exercise the most power in a certain context are also more likely to receive visibility by the media.

\section{THE U.S. SUPREME COURT}

How the media frames their reports can alter the audience's perception of events and affect their evaluation of political actors. To form an opinion, the public takes into account all the information available to them, yet it is predominantly the media that provides that information. This is problematic because the Supreme Court is relatively absent from the media and receives publicity only sporadically (Johnson 2014). This is due to the fact that the Court issues its opinions only twice a year. Covering the Supreme Court is further complicated by its highly specified rulings, which are hard to understand without legal training. However, reporters are oftentimes left to interpret the Court's decisions and to speculate about possible consequences because they lack such intensive training (LaRowe, 2010) and because their only direct contact point to the Supreme Court is the Court's Public Information Office, which hands out Court documents without explaining them (LaRowe, 2010). In trying to make sense of the decisions, journalists might focus on the Justices' personal and ideological views instead of on the legal reasoning behind the ruling (Luberda, 2008). Furthermore, reports are presented as stories to make them more accessible and easier to follow along. However, news stories also tend to be outcome-oriented and to neglect the way the verdicts are actually reached, which again makes it more likely to focus on the Justice's ideologies (LaRowe, 2010; Obbie, 2007). Yet, this is exactly what the distance between the media and the institution is meant to prevent. By detaching itself, the Court wants to encourage the perception of an apolitical institution, which is described as being guided by legal principles, instead of personal interests (Rosen, 2007), which is characteristic of politicians. Likewise, the Court wants to be seen as an entity, as opposed to Congress, which is fragmented into different parts (Rosen, 2007).

But how does the public actually perceive the Court? As Scheb and Lyons (2001) remark: "Americans may be realistic about the actual determinants of Supreme Court decision making," but nevertheless "they continue to believe in the ideal of the apolitical Court" (p. 190). What the authors refer to as an ideal apolitical Court, other researchers have termed the myth of legality (Gibson \& Caldeira, 2009, 2011; Reference Missing for this xref r72Nicholson \& Howard, 2003); it holds that the Court bases its decisions purely on legal principles that are applied through a politically neutral process that is free from the influence of personal views. Yet, their results also show that the public is well-aware of the fact that the Justices do not exercise discretion when they make decisions. The crucial point is, however, that the public believes that this discretion is characterized by sincerity and principles (Gibson \& Caldeira, 2011). Consequently, the judiciary's decision-making process is seen as fundamentally different from that of politicians, which focuses on strategy and self-interest (Gibson \& Caldeira, 2011). It follows that support for the Court is not too much affected by what it rules, but by how it reaches its verdict (Gibson \& Nelson, 2014; Gibson \& Caldeira, 2011; Ramirez, 2008). Hence, public support for the institution can be harmed if the media argued that the Justices do not follow (legal) principles, but solely act on strategic, political interests 
(Baird \& Gangl, 2006; Hamilton, 2012; Scheb \& Lyons, 2001). Generally speaking, the Court would benefit from being presented as distinctively different from political actors.

But still, media coverage of the Court is becoming increasingly politicized as previous research has shown (Johnson \& Socker, 2008; Jones, 2014). Portraying the Court as an entity would characterize it as a unified body that can clearly be distinguished from political institutions like Congress. Hence, viewing the Court as just another fragmented, political body is encouraged through references to specific groups or members of the Court as well as appealing to the sense of conflict. Taking into consideration which decisions are reported, the media's emphasis on conflict is evident; although unanimous decisions have increased over time, reporting them has become less common, while cases that divide the Court are over-reported (Johnson \& Socker, 2008; Jones, 2014). Yet, politicizing the Court in the most obvious way is achieved by directly addressing the Justices' ideological and partisan stance. Jones' (2014) corpus linguistic analysis of The New York Times articles has shown that the frequency of statements that relate the Justices to the President that appointed them has steadily increased over a time span of 60 years. Likewise, a study on Justice Samuel Alito's confirmation process (Gibson \& Caldeira, 2009) found that Alito's opponents employed a strategy that focused on his ideology and partisanship to denounce the nominee, whereas his supporters made use of symbols of judicial authority and primarily used a legitimacy frame that augmented his judicial qualifications. Other scholars investigated if personal ideological preferences affect the perception of the institution's legitimacy (Bartels \& Johnston, 2013; Nicholson \& Howard 2003). The results show that citizens' party identification and ideological stance do in fact influence their support for the Supreme Court ${ }^{5}$ after it rendered judgment. Moreover, those factors do not influence the channels' coverage equally, as Egan and Citrin (2009) note that conservatives' perception of legitimacy is more strongly affected by liberal decisions than liberals' by conservative rulings.

However, even if the media was to present the Court as politicized, they could employ certain strategies to mitigate negative repercussions. First, the notion that the Supremes act above the political realm can be reinforced by making use of symbols of judicial authority, that is, using legal jargon and showing the Court house (Gibson \& Caldeira, 2003; Gibson \& Nelson, 2014; Gibson et al., 2014). Employing legalistic terms, such as "compelling governmental interest" and "equal protection," in the coverage of the Supreme Court, triggers a cognitive response in the audiences that reminds them of the Court's judicious character. Second, perceiving the Court's procedure as fair and balanced can generate acquiescence to

\footnotetext{
5. Nicholson and Howard differentiate between diffuse and specific support. Their results show that specific support is affected by citizens' party affiliation, whereas diffuse support remains stable.
}

unpopular decisions (Gibson et al., 2010; Ramirez, 2008). Third, Nicholson and Howard found that in the aftermath of Bush v. Gore even referring to the Justices in ideological terms did not necessarily diminish their legitimacy as long as the decisions' consequences were not emphasized. In view of the prevailing lack of knowledge about the judiciary and the media's important role in giving the public an understanding of the Court, it is of special interest to analyze how the Court is presented.

\section{RESEARCH QUESTIONS AND HYPOTHESES}

As has been mentioned, the Supreme Court is largely absent from the media. Likewise, research that examines the relationship between the media and the government focuses mostly on the legislative or executive branches or if studies concern the judiciary, the focus lies on what cases are covered and for what reasons they receive attention. The studies referred to above offer several different ways how the media can present the Court. For one, it is said that reporting is outcome-oriented; however, other studies state that public support is affected by how the Supreme Court makes a decision, rather than what the decision is, which implies that media coverage would focus on the process of reaching a verdict. The decision-making process itself, then, can be framed in strategic or principled terms. In the same manner, the Court can be framed in legal or political terms. Since there is not a great amount of research on the media's framing of Supreme Court, in particular, it is useful to let the frames emerge from the material. This can be achieved by posing broad questions that do not limit the analysis to pre-set frames.

Research Question 1a: How is the Supreme Court framed when its decision reflects the channels' ideological beliefs?

Research Question 1b: How is the Supreme Court framed when its decision does not reflect the channels' ideological beliefs?

The underlying assumption is that there are differences between the channels' framing when covering the same Supreme Court decision. This assumption is based on the notion that MSNBC and Fox News can be defined as partisan channels that represent opposing poles on the ideological scale. It follows that both channels cater to audiences with distinct ideological preferences and that these preferences are reinforced by the news outlets. Since the rulings chosen for analysis can be characterized as polarizing as well, it can be assumed that the channels, when reporting the same case, employ different frames. Further, the channels' frames are expected to be of critical, if not attacking, nature when the ruling does not resemble the channels' ideological orientation, whereas frames will be less critical and rather supportive of the Court when the ruling mirrors the channels' ideological stance. ${ }^{6}$ Furthermore, the channels'

\footnotetext{
6. These assumptions refer to the concept of disconfirmation bias. According to Ditto and Lopez (1992), information that confirms individuals' preferences is more easily accepted, whereas information that challenges those views is questioned and refuted (Taber \& Lodge, 2006).
} 
framing can be explained by taking into consideration the contributors that are involved in the coverage.

Research Question 2: Who are the dominant contributors in the channels' coverage?

The broadest differentiation between the channels' featured voices is supporters of the ruling and opponents of the ruling. Since partisan news outlets tend to be one-sided, however, the channels are more likely to include voices that share their point of view. Hence, it seems more feasible to categorize the contributors differently. According to Entman's model of cascading activation, the administration and elites usually have privileged access to the media, which means that it is easy for those groups to receive visibility in the news. However, the model mostly applies to issues of national security and foreign policy because in these instances the media has only little control over the framing of events. Since the present study concerns the domestic realm as well as the judiciary, it can be assumed that different types of contributors are included in the channels' programs (Handley, 2010; Van Leuven, 2006). It is further assumed that the media plays a crucial role in the framing process regardless of whether the Court's decision reflects the channels' partisan orientation. Moreover, when the ruling complies with the channels' preferences, legal experts are expected to be the dominant contributors because their mere presence and their ability to explain the decisions' legal reasoning reinforce the Court's apolitical character. Furthermore, previous research has shown that support for a Supreme Court nominee is expressed by highlighting their legal qualifications, which again appear more convincing when defended by someone from the same field. In contrast, the nominee's opponents tend to appeal to partisanship and ideology, which is most persuasively conveyed by political contributors. Besides, people not educated in law usually do not have sufficient knowledge to fully comprehend and explain the Court's rulings, which they compensate for by describing the judiciary in political terms. Hence, it can be assumed that political contributors dominate the coverage when the decision is contrary to the channels' ideological beliefs.

Hypothesis 2a: When the ruling reflects the channels' ideological beliefs, the media and legal experts dominate the coverage.

Hypothesis $2 b$ : When the ruling does not reflect the channels' ideological beliefs, the media and politicians dominate the coverage.

Moreover, it is also important to look at the terminology the outlets use when referring to the Supreme Court. As previous studies have shown, it is crucial for public support to present the Court as being different from other political institutions, yet it has also been said that the coverage of the Supreme Court has become increasingly politicized. One possible way to reinforce viewing the Court as acting above the political realm is to refer to it as a unified entity and to deemphasize conflict between the majority and dissidents. In contrast, a politicized image of the Supreme Court presents it as deeply divided and augments the Justices' individual opinions. These possibilities lead to the question if the channels refer to the Court as an entity, if they differentiate between the majority and the dissidents, or if they place emphasis on individual Justices.

Research Question 3: Do the outlets refer to the Supreme Court as a unified entity, address individual Justices, or distinguish between majority and dissidents?

When the decision complies with the channels' partisan stance, the reports are presumed to refer to the Court as a unified entity because this encourages public support for the Court and its decisions by reinforcing the notion of judicial authority and distinguishing the judiciary from other political institutions. If, however, the ruling does not reflect the channels' beliefs, the coverage aims at discouraging support for the Court and the decision through politicizing the institution. This is accomplished either by distinguishing between the majority and dissidents or by referring to individual Justices. Since previous studies have shown that conservatives are more strongly affected by liberal rulings than liberals are by conservative rulings, a harsher reaction from Fox News is expected.

Hypothesis 3a: When the ruling reflects the channels' ideological beliefs, the Supreme Court is mostly referred to as a unified entity.

Hypothesis 3b: When the ruling does not reflect the channels' ideological beliefs, the Court is mostly referred to as a fragmented institution.

Hypothesis 3c: In addition to dividing the Court into the majority and dissidents, Fox News addresses individual Justices when the ruling does not reflect its ideological beliefs.

\section{METHODOLOGY \\ Data collection}

The aim of the present study is to understand how partisan news outlets frame the Supreme Court. These outlets tailor their news reports to reflect their audiences' ideological beliefs, which is why it can be assumed that outlets that cater to opposing ideological standpoints frame their narratives differently. To observe these differences, the present study focused on the partisan TV channels Fox News and MSNBC. Since television still is the most common medium Americans use for news consumption ("How Americans Get Their News," 2014; Olmstead Olmstead, Mark, Amy, \& Enda, 2013), television news transcripts were chosen over newspaper articles or radio shows. The decision to analyze the news coverage of Fox News and MSNBC was based on previous findings that demonstrated the contrasting nature of both channels. On the one hand, surveys have shown that their audiences identify themselves as conservatives and liberals, respectively ("Ideological Placement of Each Source's Audience," 2014). ${ }^{7}$ On the

\footnotetext{
7. For a more detailed report, see "Where Fox News's Audience Fits on the Political Spectrum," (2014) and "Where MSNBC's Audience Fits on the Political Spectrum" (2014).
} 
other hand, previous studies have defined their coverage as slanted by conservative and liberal ideology, respectively (Baum, 2012; Chalif, 2011; Levendusky, 2013b; Smith \& Searles, 2014). Hence, it can be claimed that both outlets are relevant partisan news channels that have audiences with distinct ideological beliefs; therefore, they are suitable for analyzing in how far the Supreme Court is framed differently when reporting decisions that do or do not reflect the audiences' views.

To best observe these differences, the coverage of the two highly polarizing Supreme Court decisions in Burwell v. Hobby Lobby, Inc. and Obergefell v. Hodges was analyzed. In Hobby Lobby, the Supreme Court ruled that closely-held for-profit corporations can opt out of the contraceptive mandate of the Affordable Care Act if they object to it religiously. The mandate requires employers to cover a range of contraceptives, including four that the plaintiffs believe to be equal to abortions, ${ }^{8}$ and providing these four contraceptives would substantially burden the corporation's free exercise of religion. Hobby Lobby was based on the Religious Freedom Restoration Act and was the first Supreme Court ruling that found that corporations can hold religious beliefs. The dissenting Justices argued that corporations cannot hold religious beliefs because they are not natural persons, even if they are closely-held. Although the four "conservative" Justices and Kennedy ruled in favor of Hobby Lobby, in the case of Obergefell it was him and the four "liberal" Justices that declared that bans on same-sex marriage violated the 14th Amendment ${ }^{9}$ and that the fundamental right to marry also applies to samesex couples. Hence, every state is now required to issue samesex marriage licenses and to recognize those issued by other states. The dissenting Justices argued that the Court had no authority to change the universal concept of marriage and that by legalizing same-sex marriage the Court had short-circuited the democratic process, that is, passing legislations through a representative body. The decisions in Hobby Lobby and Obergefell are especially suitable for a comparison of partisan news' coverage as both cases were decided by the same Court, meaning that differences in covering both decisions cannot be ascribed to different Justices serving. Besides, both can be defined as landmark decisions, which suggests that they possess a high-degree newsworthiness. Moreover, both cases were decided by 5:4 decisions that seemingly divided the Court along the partisan line. In like manner, Hobby Lobby can be considered as a conservative ruling, whereas Obergefell is viewed as liberal. Hence, it can be assumed that Fox News and

\footnotetext{
8. They argue that life begins at conception, which means that they object to emergency contraceptive pills and intrauterine devices because they believe that those contraceptives prevent the fertilized egg from implanting and to them, this is equal to abortion.

9. In particular, the Due Process Clause and the Equal Protection Clause.
}

MSNBC frame the Supreme Court in an asymmetrical manner when covering the same decision. Moreover, these rulings make it possible to explore if the channels frame the Supreme Court differently when they have the same response to the ruling, that is, supportive or opposing. Further, it is also possible to observe differences in each channel's coverage.

The sample includes all Fox News and MSNBC evening news transcripts from June 30th, 2014, and June 26th, 2015, respectively. Analyzing transcripts from the days the Court issued both decisions allows to see the channels' immediate responses after the ruling. Moreover, it is plausible to assume that the media's attention for a particular decision is at its peak on the day the Supreme Court issues the ruling because the media's interest in events starts to decline as their novelty decreases. Hence, stronger opinions toward the Supreme Court and its rulings might be voiced as compared to news coverage a week after the rulings. Focusing on evening news is justifiable by statistics that show that evening news have over $50 \%$ more viewers, that is, a greater reach and significance, than daytime news (Holcomb, 2016). Besides, previous research has shown that evening news shows are more opinionated than their daytime counterparts (Jurkowitz et al., 2013), which makes these programs particularly interesting for framing research. The transcripts were acquired through LexisNexis Academic by searching for both dates and channels, as well as specifying the search term as "Supreme Court." Transcripts that merely mention the Supreme Court, but did not refer to the decision were excluded. The search yielded a total of 13 transcripts.

\section{Data analysis}

As has been noted before, research about the media's framing of the Supreme Court is scarce. A deductive coding approach, that is, scanning the material for previously defined frames, restricts the process of extracting frames from the news reports to a limited set of options, which could hinder presenting a detailed and complete account of the media's narrative because other important frames were not noticed. Deductive coding approaches are usually used for processing bigger samples and when previous studies have already established certain standards. To briefly explain, in her thesis on the framing of same-sex marriage legislation in Oregon and Georgia newspapers, Anderson (2008) codes a sample of over 200 newspaper articles according to Semetko and Valkenburg's (2000) five most common media frames. The choice of a deductive coding approach is plausible for at least two reasons. On the one hand, Anderson examined a big sample of newspaper articles, which means that an inductive coding approach would be extremely time-consuming. On the other hand, previous studies from the field of framing research have analyzed legislative issues, which means that Anderson could draw from those findings as a starting point for her research. Since both of these aspects do not apply to the present study, an inductive coding approach was chosen in order not to restrict 
data collection to previously defined categories, but rather to allow for frames to emerge from the transcripts themselves. The unit of analysis is the paragraph. However, it is also possible that one paragraph contains more than one frame; in that case, the paragraph is coded for all present frames. The coding process builds on Grounded Theory (Strauss \& Corbin, 1998; Van Gorp, 2010) because this approach facilitates an interactive and flexible process. Moreover, the researcher is immersed in and connected to the material. The coding process can be understood as a dynamic rather than a linear process that involves constant comparative analysis, which means that emerging labels and categories are constantly compared to previously found occurrences. Identifying the frames is done in multiple stages: open coding, axial coding, and selective coding. During the open coding stage, which involves close reading of the material, descriptive labels are added to each paragraph. This means that the transcripts are searched for framing devices, such as symbols or particular wordings, to find out how the story is told. However, these labels cannot be described as frames yet, as they solely serve to structure the material loosely. During the next stage, axial coding, the labels that emerged from the open coding stage are reduced to more significant categories. The purpose of axial coding is to reorganize the labels in such a way to develop more precise categories that nevertheless encompass several labels. The third stage is what Van Gorp and Vercruysse (2012) refer to as developing the "frame packages" (p. 1275), which for the present study means to apply Entman's frame functions to each category in order to be able to reconstruct the channels' narratives. Besides, this adds a general structure to each frame, which serves as a basis for comparison. Again, a frame has to fulfill at least two of the following functions: defining a problem, identifying its causes, imposing an evaluation, or suggesting remedies or improvements. These functions are used as guidelines to distinguish the individual frames, as well as to describe and compare them.

After the frames have been defined, the qualitative data is coded quantitatively for individual contributors and terms for the Supreme Court in order to determine the respective distribution patterns. The contributors are divided into four groups according to their profession. The first category is the media, which includes every speaker that currently works in the journalistic field. Supreme Court Justices, attorneys, and legal educators belong to the next category, legal experts. In addition, there are political contributors. These speakers are lobbyists, political activists, and members of the legislative or executive. Contributors that do not fall into any of these categories are grouped together as "others." To analyze the terminology pattern, it is examined if the Supreme Court is addressed as a unified or a divided institution or whether individual Justices are referred to. Only the terms "Supreme Court" and "Court" are counted as a unified body. Yet, instances that refer to previous Courts, such as the Taney Court (O'Reilly, 2014, p. 5), and mentioning the Supreme Court in another way that does not concern the present Justices, such as "the Court's docket" (Kelly, 2015, p. 2), are excluded. Placing emphasis on individual Justices is done by explicitly naming them. Whereas instances that present the Court as divided distinguish between the majority and dissidents, conservatives and liberals, or males and females. In order to be able to compare the channels' different patterns, contributor and terminology both, the results from counting are converted into percentages. This is done for each frame individually but also includes the overall pattern of each channels' coverage of the particular case. It should be noted that some items are coded for multiple frames, which results in overlapping data among the individual frames. Hence, to determine the overall distribution patterns, those instances are only counted once.

By adding quantitative data to the study, the results of the qualitative analysis are enhanced. For instance, it is possible to identify patterns that are not apparent in qualitative data by analyzing quantitative data. Moreover, quantitative data add what Maxwell (1992) refers to as "internal generalizability" to the findings, which means that it facilitates generalizations for the particular case under investigation and, therefore, strengthens the overall validity of the study.

\section{Limitations}

The present study is limited in scope and analysis. On the one hand, the sample size is relatively small considering that the coverage of only two Supreme Court decisions and two partisan channels is analyzed. This means that findings cannot be generalized, yet a smaller sample allows for an in-depth analysis that does not restrict the data collection process by any preassigned categories. Since only a few studies within the field of frame analysis have previously focused the Supreme Court, this is considered to be an appropriate approach because it allows for frames to emerge from the transcripts and to give a detailed account of the channels' narratives. On the other hand, qualitative research methods raise the issues of replicability and objectivity. However, the present study attends to the concept of trustworthiness by showing consideration for credibility, dependability, transferability, and confirmability. The study's credibility is increased by utilizing methods for the coding process and data analysis that are well-established in the field of framing research. Transferability is supported by providing the necessary background information that defines the study's context. Dependability and confirmability of the present study are enhanced by disclosing the framing process (see Appendix).

\section{FINDINGS}

\section{How do the channels frame the Supreme Court?}

As already mentioned, the channels' framing is analyzed by cases that either do or do not mirror the channels' ideological views. Since Fox News is a conservative outlet, Hobby Lobby complies with its position, whereas Obergefell contravenes it. 
Consequently, Obergefell conforms to the liberal beliefs of MSNBC, while Hobby Lobby does not.

\section{The decision reflects the channels' ideological beliefs}

Fox News \& Burwell v. Hobby Lobby

In covering Hobby Lobby, Fox News employed three frames: Process, Use of Power, and Dissent. The channel generally communicates a positive view of the Supreme Court's decision on the Hobby Lobby case. Accordingly, the Process frame does not define the Court's decision-making process as problematic, but instead evaluates it as fair and lawful (Bream, 2014, p. 2; Hannity, 2014, p. 4) and serves to explain the underlying reasons. Fox News's program strongly emphasizes that the Hobby Lobby case was about religious liberty and not birth control to encourage perceiving the process as rightful (Bream, 2014, p. 11; Kelly, 2014, p. 14; O’Reilly, 2014, p. 2). This point is especially useful for viewing the Court's decision as sound and reasonable, because it refers to religious liberty, which is one of the most fundamental rights in American society and also essential to conservative ideology. Another aspect that bolsters the majority's legal reasoning is that all news shows focus on elaborating the ruling's foundation in the RFRA. First of all, to be able to argue that the RFRA can be applied to corporations like Hobby Lobby, it has to be shown that a corporation can be seen as a person. This is done by claiming that these companies are closely-held and often family-owned (Bream, 2014, p. 3; Hannity, 2014, p. 4; Van Susteren, 2014, p. 3), consequently the corporation's personality can be regarded as identical to the owner's and, thus, it is possible for the corporation's free exercise of religion to be substantially burdened. To strengthen that justification, Citizens United is referred to (Bream, 2014, p. 11), which ruled that corporations can also have free speech rights. Next, it is claimed that even if the government had a compelling interest in upholding the contraception mandate, it failed to show that there were no less restrictive alternatives to it (Bream, 2014, p. 2; Hannity, 2014, p. 4). Regarding the RFRA, this implies that the government was unable to fulfill the requirements for placing a substantial burden on somebody's religious beliefs ("Religious Freedom Restoration Act of 1993"). In contrast, it is demonstrated that the Supreme Court respected all the aspects mentioned in the RFRA and, further, applied the principle of strict scrutiny. The principle of strict scrutiny, like the RFRA, requires a compelling governmental interest and achieving said interest by the least restrictive means, but it also states that a law or decision has to be nartrly tailored (Winkler, 2006, p. 800). Fox News's reports excessively focus on the latter two points, hence the audience is constantly told that the ruling only concerns closely-held for-profit corporations that have sincere religious beliefs that would be burdened by providing for those four specific contraceptives (Bream, 2014, p. 2; Kelly, 2014, p. 14; Van Susteren, 2014, p. 2). By using the same wording as the RFRA to explain the legal reasoning behind the ruling and by appealing to important conservative values, such as religious liberty and individual responsibility, the majority's decision-making process is framed as lawful.

As the majority's decision-making process, the way the Court uses its powers is also framed in a positive way and is not described as problematic. It is important to note that, here, the entire Court is addressed, which emphasizes its function as the third branch of government. Fox News's news shows give special attention to two central aspects of that function: applying the law and ensuring that the other two branches of government do not impinge on the American people's rights. Hence, it is repeatedly asserted that the government, that is, either the administration or the U.S. Department of Health and Human Services, would substantially burdened the free exercise of religion of closely-held corporations by forcing them to comply with the contraceptive mandate of the Affordable Care Act (Bream, 2014, p. 2; Hannity, 2014, p. 1; Kelly, 2014, p. 14; O'Reilly, 2014, p. 2). Moreover, it is claimed that an expanding government inevitably entails that the people's rights are violated at some point (Bream, 2014, p. 11), which encourages viewers to perceive the Supreme Court as a necessary counterpart to the administration that guarantees their rights and constrains the government's power when necessary. Fox News's reporting especially emphasizes the latter point. Through frequent juxtaposition of the Supreme Court and the administration as well as through frequent use of expressive language, such as the Court "deals a sharp blow to President Obama" (Bream, 2014, p. 1), it is asserted that the Court is willing to act when the government oversteps its boundaries (Kelly, 2014, p. 14). Likewise, it is also said that Justice Kagan, who formerly worked for the President, decided against him in National Labor Relations Board v. Noel Canning (Kelly, 2014), which encourages a perception of the Justices as independent regardless of their background. In addition, the Court as a whole is referred to, which makes it appear more powerful since the Justices are described as a unified body. Thus, the administration is presented as impinging on the people's rights, violating the First Amendment (Bream, 2014, p. 9), and exceeding its institutional boundaries, whereas the Court is described as strong, not hesitant to act when needed, and as being able to protect the Constitution.

However, this view changes when the Court is not reported as a whole and the dissenting Justices are focused on. It is explained that due to different ideological prisms, the dissenters attached more importance to women's access to contraceptives than to the right of religious liberty, consequently they are described as "scary" (Kelly, 2014, p. 15), "disturbing" (O'Reilly, 2014, p. 2), and "unbelievable" (Hannity, 2014 , p. 7). Similarly, it is argued that they also want taxpayers to fund abortions and to deny rights granted by the Constitution (O'Reilly, 2014, p. 2). Citing the dissent solely serves to demonstrate that the concerns they raised are generally unreasonable and also had been addressed and refuted in the majority's opinion (Bream, 2014, p. 3). 
However, one of these concerns is argued against in more detail: the issue of an alleged war on women. Fox News's counterarguments (Kelly, 2014, p. 14; 0’Reilly, 2014, p. 4), indicating that women's access to contraception has not been impeded, appear particularly strong because they are brought forward almost entirely by women, consequently the dissenter's allegation seems questionable. Another strategy that is used to discredit the dissenting Justices and to present them as incapable of functioning as an independent branch of government, is putting them in relation to the legislative and executive and implying that they are influenced by politicians to make decisions in a way that supports the government's agenda (O'Reilly, 2014, p. 7; Van Susteren, 2014, p. 6). In the same sense, it is argued that because the liberal Justices do not base their decisions on the founding fathers' original intent, but treat the Constitution as an evolving document, they rule "politically" (O'Reilly, 2014, p. 8). This point is especially important because even if the Justices rule according to their ideological preferences, they have to base their decisions on legal principles and respect the corpus of American law. Besides, as already mentioned, the notion of the founding fathers' intent especially appeals to conservatives. All these negative arguments presented against the dissenting Justices lead Fox News anchor Bill O'Reilly (2014) to draw the conclusion that if one more liberal Justice is appointed, "freedom in America will be compromised forever" (2). In addition, he states that those Justices will never vote for gun freedom or restricting abortion rights (O'Reilly, 2014, p. 5) and compares a liberal Court to the Taney Court (O’Reilly, 2014), which issued the Dred Scott decision. That comparison heightens the perceived threat liberal Justices allegedly pose to the American people's freedom by juxtaposing a predominantly liberal Court and the Court that deprived African-Americans of freedom by ruling they be excluded from U.S. citizenship and, further, that Congress had no right to prohibit slavery. Consequently, to not be at the mercy of such a Court, an improvement for the future would be not to assign another liberal Justice to the bench (O’Reilly, 2014, p. 5).

\section{MSNBC \& Obergefell v. Hodges}

Covering the decision that legalized same-sex marriage nationwide, MSNBC's programs framed the Court's decisionmaking process as well as opposing opinions. The Process frame greatly encourages perceiving the Court as working to rule through frequently addressing high-ranking liberal values, such as freedom (Hayes, 2015, pp. 3-5; Maddow, 2015, p. 5) and equality (Hayes, 2015, pp. 2-4; Maddow, 2015, p. 5-6), and also arguing that the opposite of equality, that is, discrimination, is considered "unconstitutional" (Hayes, 2015, p. 4). Besides, viewing the decision as lawful is encouraged by asserting its basis on legal principles and long-standing precedent. For this purpose, MSNBC refers to Justice Kennedy, who declared that the Constitution grants everybody the right to "equal dignity" (Maddow, 2015, p. 3), and frequently states that the ruling is based on the 14th Amendment (Hayes, 2015, pp. 2-3) as well as on the fundamental right to marry (Maddow, 2015, p. 3). Referring to former Supreme Court cases, such as Loving v. Virginia (Maddow, 2015, p. 5) and Hollingsworth v. Perry and United States v. Windsor (Hayes, 2015 , p. 4) serves to demonstrate the current case's basis in legal precedent. Dating back to 1967, Loving was the first Supreme Court case that paved the way for Obergefell $v$. Hodges, ruling that "restricting the freedom to marry solely because of racial classifications violates the central meaning of the Equal Protection Clause" (Loving) and declaring Virginia's anti-miscegenation laws unconstitutional. Windsor, on the other hand, was the most recent Supreme Court case concerning the rights of married same-sex couples, which struck down part of the Defense of Marriage Act because it denied same-sex couples federal recognition of their marriage and, therefore, it imposed disadvantages and stigma on those couples. Due to the high level of cultural resonance of Loving and Windsor, these references are likely to trigger a positive cognitive response that reveals the parallel reasoning in all three cases even without further recounting the underlying principles. Moreover, these cases put Obergefell into a historical context and show that it was the result of an enduring struggle for marriage equality.

While the legitimacy of the majority's legal reasoning is asserted, opposing voices are refuted and framed in a way that bolsters the Process frame. It is said to be "unusual" (Hayes, 2015, p. 9) that each of the dissenting Justices wrote their own opinion (Hayes, 2015, pp. 8-9), yet perceiving them as convincing is counteracted by selecting opposing arguments that do not appeal to a liberal perspective. For one, to reject the dissents is encouraged in that Justice Scalia's qualifications for the role of a Supreme Court Justice are called into question by denouncing his temperament and by referring to his mockery of the majority (Hayes, 2015, p. 8; Maddow, 2015, p. 6). The counterframe is presented as defining the Supreme Court's decision as "invalid" (Hayes, 2015, p. 8) and accusing the majority of depriving the people of the opportunity to solve the issue through a democratic process (Hayes, 2015, p. 9; Maddow, 2015, p. 6). However, the audience is reminded of the Supreme Court's duty to protect fundamental rights and that this does not necessarily have to pass through a legislative process, where elected representatives decide on issues, but that the Court functions as the "final arbiter" (Maddow, 2015, p. 6) in these cases. Hence, although the concern is voiced that the Court short-circuited the democratic process, it is argued that it was allowed to do so because it vindicated the people's rights. This argument is further strengthened by showing President Obama's support for the Supreme Court decision, which he described as "justice that arrives like a thunderbolt" (Maddow, 2015 , p. 5). The dissenters' perspective is ascribed to an approach of judicial restraint (Hayes, 2015, p. 9), which cautions judges to interpret, and not reinterpret, the Constitution and holds that the Justices should not assume a legislative 
function, but rather grant deference to the legislature. However, since basing decisions on the founding fathers' original intent is a belief more common for conservatives than liberals (Kiley, 2014), this explanation functions as a tool to reinforce the audience's views in that it reminds them of the incompatibility of both ideologies. Likewise, the finality of Supreme Court decisions (Maddow, 2015, p. 4) is asserted when opponents are introduced that reject the decision (Maddow, 2015) and want to pursue a constitutional amendment (Hayes, 2015, p. 4) because the Constitution was misinterpreted (Hayes, 2015, p. 8).

\section{The decision does not reflect the channels' ideological beliefs}

Fox News \& Obergefell v. Hodges

The reporting of Obergefell $v$. Hodges on Fox News involved framing the Supreme Court in terms of its decision-making process and its use of power. The Process frame serves to define the Supreme Court's decision-making process as flawed and to claim that the majority, consisting of "the four liberals and Kennedy" (Kelly, 2015, p. 3), had based their decision on an invented right to equal dignity (Baier, 2015, p. 10; Kelly, 2015 , p. 3). Throughout Fox News's coverage, the existence of a right to dignity is questioned, whereby the ruling's foundation is attacked to cast doubt on the legal reasoning behind it. These doubts could be balanced by discussing and explaining the majority's opinion, which is in fact cited a few times in both news shows, but instead of clarifying the underlying principles it is immediately challenged. This is done by quoting the dissenting Justices, who, for example, question the decision's constitutionality (Baier, 2015, p. 3; Kelly, 2015, p. 2) and raise concerns about the consequences for people with religious objections to the ruling (Baier, 2015, p. 3; Kelly, 2015 , p. 4). Referring to the dissidents is particularly effective because, on the one hand, they are members of the Supreme Court as well, which makes them authoritative figures that the public believes to be knowledgeable. In addition, Chief Justice Roberts' title is mentioned every time he is named, whereby the weight of his dissent is heightened by appealing to his authority. ${ }^{10}$ Second, by repeatedly reminding of the fact that all four dissenting Justices issued their own opinion (Baier, 2015 , p. 3; Kelly, 2015, p. 1) their stance appears to be especially strong, while it also raises doubt to the rightfulness of the majority's decision. Third, the opposing arguments include culturally resonant symbols, such as the Declaration of Independence (Baier, 2015, p. 10; Kelly, 2015, p. 2), the Constitution (Baier, 2015, p. 3; Kelly, 2015, p. 2), and religious liberty (Baier, 2015, p. 11; Kelly, 2015, p. 2). By referring to symbols widely known in American culture and values cherished by conservatives, the dissenters' positions become

\footnotetext{
10. Although the Chief Justice does not have any special powers, including Roberts' title is likely to reinforce the notion of judiciousness.
}

more accessible and are easier to relate to for Fox News's audience as compared to the majority's newly created right (Baier, 2015, p. 10; Kelly, 2015, p. 2). The issue of religious liberty also serves to question the majority's legal abilities when it is addressed by Fox News correspondent Shannon Bream, who recounts previous cases, when remaining true to one's religious beliefs resulted in legal consequences, such as the case of a photographer, who was "punished" (Kelly, 2015, pp. 1-2) for refusing to work at a same-sex wedding. One the one hand, this example weakens the trustworthiness of Kennedy's reassurance that supporters of traditional marriage do not have to fear negative consequences for the First Amendment will protect them. On the other hand, it also implies that the ruling might not comply with the entire corpus of American law, which is a prerequisite for rightful decisions. The general position that is presented in Fox News's program is that even if one supports the outcome, one should disagree with the way it was reached. Since the ruling cannot be defined as one of "legal judgment" (Baier, 2015, p. 3; Kelly, 2015, p. 1), but rather as an order of "will" (Baier, 2015; Kelly, 2015), it becomes "political" (Kelly, 2015, p. 2) and the Supreme Court is seen as a "threat to American democracy" (Baier, 2015, p. 10). It follows that the Justices should rely on the Constitution and also abide by the founding fathers' intent to prevent political and unconstitutional decisions.

In addition to denouncing the majority's decision-making process, how the Justices use their powers is also defined as problematic. This frame discusses the institution's appropriate role and the limits of the Justices' power. While the dissenting Justices are presented as respecting the limitations of their office, parts of their opinions are used to rebuke the majority, such as Justice Scalia's remark that the Court has become a "threat to American democracy" (Baier, 2015, p. 10), which stands in stark contrast to President Obama praising its actions as "justice arriving as a thunderbolt" (Baier, 2015, p. 3). However, most other contributors on Fox News's programs also share the opinion that the Justices acted outside their boundaries. For one, it is argued that the Court supported the President's agenda to legalize same-sex marriage nationwide and helped him achieve his goal (Kelly, 2015, p. 5). Thereby, the Court's integrity and impartiality are called into question as it appears to have actively supported a legislative effort and, consequently, the institution's independence is doubted, which is essential to a well-functioning judiciary and democracy. Second, the Supreme Court is said to have shortcircuited the democratic process by "declaring" (Kelly, 2015, p. 1) same-sex marriage the law of the land instead of letting the issue be solved through the legislative body. The problem here is that the Supreme Court Justices are neither directly accountable to any of the other two branches of government nor are they elected by the public, which means that they cannot function as a representative body declaring laws. Hence, the majority is presented as exceeding their jurisdiction and abusing their power by solving a legislative issue. 
To further encourage perceiving the majority as acting unlawfully, Scalia's dissent is quoted, stating that the majority's handling of the case "[robbed] the People of the most important liberty they asserted in the Declaration of Independence and won in the Revolution of 1776: the freedom to govern themselves" (Baier, 2015, p. 10). By evoking patriotic feelings in the viewers and by directly referring to them, the presented arguments appear more convincing. Further aiding the persuasiveness of that position are the statements by Guy Benson, a homosexual Republican Fox News contributor, who supports the outcome, but feels "trepidation" (Kelly, 2015, p. 14) because he too thinks that declaring laws is not the appropriate role of the judiciary. However, according to Fox News's program, the Supreme Court did not only overstep the line of institutional jurisdiction, but it also exceeded its authority by redefining the concept of marriage. That point is especially emphasized by Mike Huckabee (Kelly, 2015, p. 2). Besides, Chief Justice Roberts is quoted asking "just who do we think we are?" (Baier, 2015, p. 3; Kelly, 2015, p. 1) and the Archdiocese of Washington is referred to stating that the Court's decision will not change their definition of marriage (Baier, 2015, p. 3). On the one hand, this again challenges the Court's authority as well as the finality of its decisions. On the other hand, Fox News presents opposing views from three different perspectives: a legal, a political, and a religious, which adds weight to the opposition and offers different possible ways to agree with it. Generally speaking, Fox News's program does not argue for the lawfulness of the Supreme Court's action. The few claims defending the Court's handling of the case (Kelly, 2015, pp. 4-5) are unable to counterbalance the opposing views presented throughout Fox News's shows, because either the contributors do not receive enough time to elaborate their views (Kelly, 2015, pp. 9-13) or they are challenged immediately by declaring the decision "unconstitutional" (Kelly, 2015, p. 2) as well as negating its finality. In fact, it is argued that when the Court rules by "judicial tyranny" (Kelly, 2015) its decisions do not have to be accepted, and it is possible to pursue a constitutional amendment like it was done in the case of Dred Scott, a case widely known in American society. As it has become symbolic for dividing the country and restricting freedom, referring to the Dred Scott decision strengthens opposing the current ruling tremendously. In sum, the decision is seen as a "loss for (...) democracy" (Baier, 2015, p. 10) because the Supreme Court overstepped its authority by creating a new fundamental right, by making law, and by redefining marriage. A way to avoid such "imperial" rulings (Kelly, 2015, p. 2) would be to settle those kinds of issues through the elected officials of the legislative (Baier, 2015, p. 11), and not to short-circuit the democratic process.

\section{MSNBC \& Burwell v. Hobby Lobby}

The Hobby Lobby decision as reported on MSNBC presents the audience with a Process and a Legal Abilities frame.
The Process frame defines the legal reasoning behind the ruling as dubious by addressing several aspects, such as the right to religious freedom and procedural fairness. First, the majority's legal reasoning is challenged by arguing against their application and understanding of the right to religious liberty. This argument is advocated mostly by Reverend Gaddy, who defines the Court's action as an "offense to what the Constitution promises us in the religion clauses" (Maddow, 2014, p. 9). Moreover, he explains that the First Amendment is best used to protect the weak from the powerful and the right to religious liberty does only go so far as it does not harm another person's freedom. Yet, it is argued that this is the case in Hobby Lobby as the employers' ideology can now be imposed upon their employees (Hayes, 2014, p. 5; Sharpton, 2014 , p. 5). In addition, Justice Ginsburg is presented as taking a similar stance (Sharpton, 2014, p. 5) and is quoted saying that the right to religious freedom does not apply to legal entities, but only to natural persons (Hayes, 2014, p. 2). Second, it is mentioned, that the majority suggested having the government pay for those four contraceptives to counterbalance the disadvantage the ruling might cause for women. Yet, this idea met with harsh criticism from Justice Ginsburg (Maddow, 2014, p. 6) and Dahlia Lithwick, who says it is highly unlikely that the government will cover for those contraceptives, referring to the Hyde Amendment and the Hyde Amendment Plus (Maddow, 2014, p. 6), which "prohibit the expenditure of Federal funds for abortions" (Hyde Amendment Codification Act). Third, the legal reasoning is challenged because the ruling is exclusively about birth control, which raises the question if other religious groups, such as Scientologists or the Jehovah's Witnesses, can now come forward to object to other health care services as well (Maddow, 2014, p. 9; O'Donnell, 2014, p. 3; Sharpton, 2014, p. 5) or, if that was not the case, does the ruling imply the Supreme Court favors one religion over the other (O'Donnell, 2014, p. 2)? The latter question is posed by Justice Ginsburg, who also reminds of the Constitution's Establishment Clause of the Religion Clause, which prohibits the government from prefer one religion to another. Besides, it is claimed that Justice Alito did not sufficiently explain the legal principles that connect the different elements of the ruling, whereby the decision's statutory basis is weakened (Maddow, 2014, p. 5). Adding to this point, MSNBC mentions the Religious Freedom Restoration Act in only two of four news shows (Hayes, 2014, p. 3; O'Donnell, 2014 , p. 2), which might result in a distorted understanding of the legal reasoning behind the ruling. In fact, it is also argued that Hobby Lobby was not about the RFRA, but about the Affordable Care Act (Hayes, 2014, pp. 4-5), consequently a political motif seems more reasonable than the primary reason being to protect the American people's rights. Moreover, the procedural fairness of the hearings is questioned, which further enhances the negative evaluation of the majority's decision-making process encountered throughout MSNBC's program (Hayes, 2014, p. 3). By challenging several aspects 
of the majority's opinion and doing so from different perspectives, that is, religious, legal, and public, adds to the persuasiveness of the arguments encountered on MSNBC.

The Court's legal abilities are evaluated as disappointing and insufficient (Hayes, 2014, p. 5; Maddow, 2014, p. 5) by presenting the Court's workings as characterized by uncertainty, inequality, and political motivation. The issue of uncertainty can be attributed to the Court's inadequate communication skills, which is underlined when the ruling is shown to be unclear and to lack essential definitions (O'Donnell, 2014, p. 1), such as what is considered to be a sincerely held belief (Maddow, 2014, p. 9; O'Donnell, 2014, p. 4). The sense of uncertainty is particularly conveyed through indirect speech and by guessing what the majority thought (Maddow, 2014, p. 5; O'Donnell, 2014, p. 6). Likewise, Justice Alito's attempts to dismiss concerns about possible consequences of the decision are presented in a very simplified way (Maddow, 2014, p. 5; Sharpton, 2014, p. 5), whereby his qualifications to serve on the Supreme Court seem dubious. Although the entire Court's qualifications and "good faith" (Hayes, 2014, p. 5) are also called into question, a special focus is placed on the majority when stating that a case concerning birth control was decided by an all-male majority (Hayes, 2014, p. 2; Maddow, 2014, p. 4; O’Donnell, 2014, p. 3; Sharpton, 2014, p. 4) that neither possesses the required knowledge to make qualified decision on that issue, nor cares about the women affected by it (O'Donnell, 2014, p. 3). It is asserted that the majority failed to protect the fundamental right to equality and does not understand that their decision discriminates against women (Hayes, 2014, p. 2). To illustrate the Court's inconsistent behavior, other cases are mentioned that declared discriminating against others because of their gender or race as unconstitutional, even if founded on religious beliefs (Maddow, 2014 , p. 7). Another example of that "mind-boggling" (Hayes, 2014 , p. 5) inconsistency is given by referring to a recent Supreme Court decision that denied abortion clinics bigger buffer zones due to the right to free speech (McCullen $v$. Coakley). It is argued that while not being in danger because of attacks by angry protesters, the Supreme Court's zone is seven times bigger as compared to abortion clinics' (Hayes, 2014 , p. 5), whereby it is implied that the Court is not only inconsistent with its legal reasoning, but also able to elude being held accountable and taking full responsibility for its rulings. Besides, it is argued that the Court has been overstepping its jurisdiction for a while by engaging with politics (Hayes, 2014). This can become problematic when the motivation behind the Court's decisions is perceived to be of political, rather than legal nature as well. As in the case of Hobby Lobby, it is claimed that the political right has had an effect on the Court's decision (Sharpton, 2014, p. 5) and that the Court is too involved in the political sphere. Considering that the Justices have too much power and do not respect the limitations of their office, it is proposed that the Court needs to be brought under the "same code of ethics that all federal judges are under" (Hayes, 2014, p. 5) to exercise more control over it.

\section{Who are the dominant contributors?}

Figure 1 presents the findings from analyzing the distribution of contributors for each channel and each ruling, respectively. Fox News's coverage of the Hobby Lobby decision is delivered by media and legal sources for the most part. However, it should be noted that almost half of the media's statements are contributions by journalists with an education in law. This adds to the positive effect of the prevailing statements that encourage praise for the ruling, because these contributors, as opposed to politicians, are more able to convey a sense of judicial uniqueness and reinforce the notion of judicial authority by supporting the Court's ruling. In addition, political voices are barely included, whereby the legal and the political spheres are further set apart. In contrast to the subtly legal focus that viewers encounter on Fox News when the decision reflects the channel's beliefs, MSNBC's reporting aims at an empathetic perception through primarily including statements by Lesbian, gay, bisexual, and transgender rights supporters. Moreover, it can be said that journalists are the dominant contributors, while legal experts and political sources are featured less frequently. The same pattern has been found in Fox News's coverage of Obergefell, yet the conservative programs include a greater number of contributors that oppose the concept of same-sex marriage. Moreover, the share of legal experts decreased, whereas political contributors were featured more often as compared to covering a ruling supported by the conservative outlet. This observation holds also true for MSNBC's reports of Hobby Lobby that mostly draw on sources from the journalistic and political fields. What is also striking, is that the channel's news reports feature a higher number of female voices and more contributions by speakers who are supportive of contraception. Hence, the frequently presented argument that the Supreme Court's ruling causes women great disadvantages gains weight because it is brought forth by those affected by it. Therefore, the reporting of MSNBC and Fox News seemingly appeals to

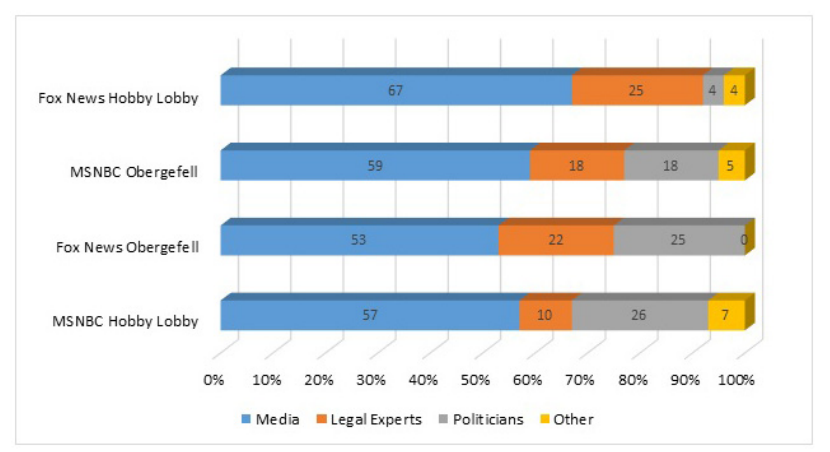

Figure 1. Contribution Pattern. 
different aspects with the latter focusing on a legal connotation, whereas the former emphasizes a human interest.

Table 1 shows the contribution patterns for each frame. Regarding Hobby Lobby, Fox News's program almost entirely frames the dissenters by the media. While journalists also play an important role in the Process and Use of Power frames, the number of legal experts noticeably increases. In contrast, on MSNBC all three contributor groups frame the decisionmaking process in Obergefell to almost equal parts, whereas the opposition is framed entirely by media sources. Turning to the Justices' use of power in Fox News's reports on Obergefell, most can be ascribed to the media. Yet, political contributors also play a considerable role. With regard to the Supreme Court's decision-making process, the coverage is dominated by media sources and legal experts and politicians are equally involved. The media is also the dominant group framing the Supreme Court's decision-making process in MSNBC's reporting of Hobby Lobby. Legal experts are rarely involved and are in fact outweighed by political voices. The same holds true for the Justices' legal abilities, which are predominantly framed by politicians, followed by the media.

The findings support Hypothesis 2a and Hypothesis 2b, which predicted that the media and legal experts dominate the channels' coverage when the ruling reflects the channels' ideological beliefs, and if the decision does not reflect the channels' beliefs, their coverage predominantly features media and political contributors. This pattern also shows when looking at the individual frames used when the channels support the decision. Regarding the framing of the opposition and dissenters, it can be observed that the shares of media and political sources increase, whereas legal experts are included less frequently.

\section{How is the Supreme Court referred to?}

Figure 2 visualizes how the Supreme Court was addressed in each case. With regard to covering the Hobby Lobby decision,

Table 1. Frame-specific distribution pattern.

\begin{tabular}{lccccc}
\hline & $\begin{array}{c}\text { Media } \\
\text { (\%) }\end{array}$ & $\begin{array}{c}\text { Legal } \\
\text { experts } \\
\text { (\%) }\end{array}$ & $\begin{array}{c}\text { Politicians } \\
\text { (\%) }\end{array}$ & $\begin{array}{c}\text { Other } \\
\text { (\%) }\end{array}$ & $\begin{array}{c}\text { Total } \\
\text { (\%) }\end{array}$ \\
\hline $\begin{array}{l}\text { Fox News Hobby Lobby } \\
\quad\end{array}$ & 59 & 33 & 2 & 6 & 100 \\
$\quad \begin{array}{l}\text { Process } \\
\text { Use of power }\end{array}$ & 67 & 24 & 0 & 9 & 100 \\
$\quad$ Dissenters & 76 & 10 & 7 & 7 & 100 \\
$\begin{array}{l}\text { MSNBC Obergefell } \\
\quad \text { Process }\end{array}$ & 36 & 29 & 29 & 6 & 100 \\
$\quad$ Opposition & 100 & 0 & 0 & 0 & 100 \\
$\begin{array}{l}\text { Fox News Obergefell } \\
\quad \text { Process }\end{array}$ & 50 & 25 & 25 & 0 & 100 \\
$\quad$ Use of power & 60 & 14 & 26 & 0 & 100 \\
$\begin{array}{l}\text { MSNBC Hobby Lobby } \\
\quad \text { Process }\end{array}$ & 72 & 10 & 13 & 5 & 100 \\
$\quad$ Legal abilities & 32 & 13 & 47 & 8 & 100 \\
\hline
\end{tabular}

Fox News predominantly addresses the Supreme Court as a unified institution, yet the Court is also frequently described in terms of different divisions, whereas referring to specific Justices is least common. As to MSNBC's reporting of Obergefell, the three representations are rather balanced, yet the shares of characterizing the Court as fragmented and referring to specific Justices are slightly greater than describing the Court as an entity. It should also be noted that the balance of presenting the Court as divided and referring to individual Justices is leveled, and these instances mostly serve to highlight the dissenting opinions. Reports on Obergefell on Fox News rarely portrays the Court as an entity. Instead, attention is drawn to the incompatible standpoints of the majority and the dissenters by dividing the Court into opposing fractions, such as "conservatives" and "liberals" (Kelly, 2015 , p. 3). In addition, the reports place equal emphasis on individual Justices, which augments the perception of an existing conflict and allows to illustrate that conflict by clearly defining and juxtaposing the opposing views. Moreover, this attributes statements to specific Justices and in doing so it is possible to denounce the majority, while being supportive of the dissenting Justices. In contrast to Fox News, MSNBC balances each of the three possibilities.

Table 2 illustrates how the Supreme Court is characterized in the specific frames. In regard to Hobby Lobby, Fox News's Process frame presents the Court mostly as an entity or as divided into different groups, whereas pointing to specific Justices is less common. The same holds true for the Use of Power frame, although the shares are more clearly distinguishable there. However, when the dissenting Justices are framed, the Court is said to be fragmented and the Justices are named more frequently. The same holds true for MSNBC's Opposition frame in reporting Obergefell, whereas the Court is mostly described as an entity when the decision-making process is explained. In contrast to conveying a sense of consensus, Fox News's Process and Use of Power frames of the same case emphasize the notion of conflict heavily by predominantly referring to a fragmented Court and specific Justices. With regard to MSNBC's reporting of Hobby Lobby, the Legal Abilities frame mostly focuses on the Court as a divided institution. However, this is closely followed by

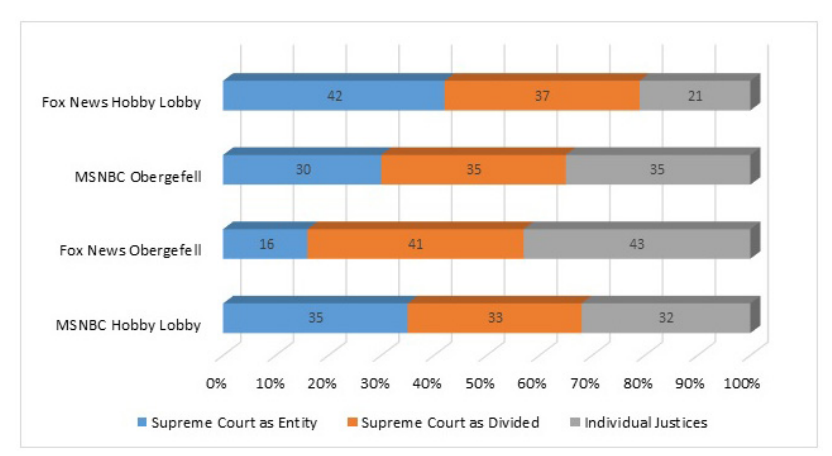

Figure 2. Terminology Pattern. 
Table 2. Frame-specific terminology patterns.

\begin{tabular}{lcccc}
\hline & $\begin{array}{c}\text { Supreme } \\
\text { Court as } \\
\text { entity (\%) }\end{array}$ & $\begin{array}{c}\text { Supreme } \\
\text { Court as } \\
\text { divided (\%) }\end{array}$ & $\begin{array}{c}\text { Individual } \\
\text { Justices } \\
\text { (\%) }\end{array}$ & $\begin{array}{c}\text { Total } \\
\text { (\%) }\end{array}$ \\
\hline $\begin{array}{l}\text { Fox News Hobby Lobby } \\
\quad \text { Process }\end{array}$ & 39 & 37 & 24 & 100 \\
$\quad$ Use of power & 52 & 33 & 15 & 100 \\
$\quad$ Dissenters & 17 & 53 & 30 & 100 \\
$\begin{array}{l}\text { MSNBC Obergefell } \\
\quad \text { Process }\end{array}$ & 50 & 25 & 25 & 100 \\
$\quad$ Opposition & 10 & 45 & 45 & 100 \\
$\begin{array}{l}\text { Fox News Obergefell } \\
\text { Process }\end{array}$ & 9 & 41 & 50 & 100 \\
$\quad$ Use of power & 24 & 38 & 38 & 100 \\
MSNBC Hobby Lobby & 35 & 29 & 37 & 100 \\
$\quad$ Process & & & & \\
$\quad$ Legal abilities & 35 & 42 & 23 & 100 \\
\hline
\end{tabular}

instances that describe the Court as an entity. Likewise, the decision-making process refers to the Court as a whole and to individual Justices equally frequent.

With regard to these findings, Hypotheses $3 a, 3 b$, and $3 c$ are supported by the findings. However, this is only evident when considering the terminology patterns of the individual frames, since the general distribution for MSNBC exhibits a pattern opposite to the hypotheses. Yet, the channel's coverage of Obergefell also frames the opposition, which means that part of the overall terminology pattern includes instances that MSNBC disagrees with and responds to differently than when voicing support.

\section{DISCUSSION}

The present study examined how partisan news channels, Fox News and MSNBC in particular, frame the U.S. Supreme Court by first conducting a qualitative frame analysis to reconstruct the channels' narratives. Then, the respective contribution and terminology patterns were determined. The analysis yielded four important findings. First, the findings generally suggest that partisan channels do not frame the Supreme Court as an institution, instead the frames focus on the Court's manner of operating, such as the decision-making process and how the Court uses its powers. Framing specific aspects of the Court instead of the institution itself is comparable to previous studies, which found that public support for the judiciary is greatly influenced by how the Court reaches its decisions and by defining that process as fundamentally different from political decision-making (Gibson \& Caldeira, 2009; Ramirez, 2008). On the one hand, news channels cater to an audience, therefore it seems reasonable that their programs focus on what is important to their viewers. On the other hand, the media also has the power to shape public discourse and to affect public opinion. To do so in the most effective way would mean to focus on those aspects that have the greatest effect on the public and to frame those in a certain way. Besides, the Supreme Court is detached from the public and holds a lot of prestige, consequently not framing the Court itself, but specific institutional aspects makes the frames more accessible for and familiar to the audience. For instance, this offers the opportunity to compare the judicial decision-making process to political processes, which generally are more familiar to the audience. In the same manner, the Supreme Court is mostly mentioned as a divided institution or by referring to individual Justices. This adds to familiarizing the audience with the Court, because it puts a human face on the institution, whereas referring to the Court as an entity would further the distance between the Justices and the public. Besides, describing the Court as divided into two groups appeals to the concept of bipartisanship, which the public is familiar with because it is a defining characteristic of American politics. Moreover, it is easier to either oppose or support a particular group than the entire Court. Whereas the Court as an institution combines the Justices' individual ideologies, separate groups exhibit distinct values more clearly and for this reason people are able to identify with them more easily. Yet, finding that the Supreme Court is more frequently mentioned as a divided institution is contrary to LaRowe's (2010) study, which found that the Supreme Court is mostly referred to as an entity. However, there are several differences that could explain the contrary findings. First, LaRowe analyzes newspaper articles from 1997 to 2004 of The New York Times and USA Today, two left-leaning newspapers. In contrast to LaRowe's study, the present one focused on partisan news channels coverage of two specific cases from 2014 to 2015, respectively. Hence, the opposite findings could be due to analyzing different media, different political leanings, or different timeframes. Considering polarization has heavily increased over the last 10 years, the latter point seems especially feasible because that could be reflected by dividing the Court into two opposing groups.

Second, when the ruling reflects the channels' ideological beliefs the Court is presented as being different from other political institutions. For one, this is achieved by emphasizing the legal principles and the precedent the ruling is grounded in. Thereby, the judicial decision can be clearly distinguished from a political one, because it is principled and consistent with past decisions, whereas politicians are characterized as guided by strategy and having the tendency to waffle. Besides, this encourages viewing the decision as upholding the Constitution and, thereby, defining it as rule of law, whereas political decisions resemble rule of men. This finding complies with other studies that found that support for Supreme Court decisions or Supreme Court nominees is expressed through frames that assert the ruling's foundation on legal principles and that emphasize the nominee's legal qualifications (Gibson \& Caldeira, 2009; Reference Missing for this xref r72Nicholson \& Howard, 2003). Moreover, referring to legal principles holds the audience at a distance from the Supreme Court as the public usually lacks a deeper understanding of the law and needs experts to explain the Court's legal 
reasoning. As a consequence, when the channels support the ruling the media functions as a link between the public and Court, which entails that most statements are made by journalists as well as that the channels present legal experts more often than when they oppose the ruling in order to help the audience understand the decision. In contrast, only a few political voices are included. This further encourages the audience to distinguish the judiciary from the political realm because they encounter different contributors than during political reports. In addition, when the Court's decision-making process is framed, the Supreme Court is referred to as an entity more frequently than as a collection of individuals. Hence, the programs appeal to the notion of consensus, rather than conflict, which again sets the judiciary apart from political institutions. It should be noted, however, that Fox News explicitly underlines the judiciary's distinctiveness by framing the Supreme Court as a counterweight to the administration. In these instances, the Justices are described as strong as well as not hesitant to act when the administration exceeds its institutional boundaries. This line of argumentation can be explained by the fact that Fox News is a conservative news outlet, which means that its audience generally opposes a Democratic administration and the channel will thus use any available means to denounce the administration's actions, while also reinforcing the audience's ideological beliefs. However, this frame is not present in MSNBC's programs. On the one hand, MSNBC is generally supportive of a Democratic administration because it is a left-leaning news channel. On the other hand, the administration openly advocated marriage equality, which means that the channel had no reason to object to neither the Court's decision, nor the executive's position because both resonate with liberal ideology.

Third, when the ruling does not reflect the channels' ideological beliefs the Supreme Court is framed in a politicized manner. To begin with, the majority's decision-making process is framed as similar to political processes by presenting it as strategic or even defining the decision as outright political. Whereas, Justices are supposed to be impartial and ensure a fair process, the political decision-making is characterized by self-interest. In that manner, it is argued that the Justices did not apply the law in a consistent manner, but instead bent it to fit their preferred outcome. To further encourage this perception, the legal reasoning behind the rulings is explained insufficiently and the majority's opinion is presented as vague, which prevents a thorough understanding of the decision and implies the Justices are incapable of communicating efficiently. However, this also addresses the issue of transparency, which is a means to hold the otherwise isolated Court accountable. Moreover, both channels claim that the majority pursued precise goals and was biased in making their decision, which reminds of political strategy rather than legal principles. Thus, both channels call the Justices' impartiality and integrity into question. Yet, Fox News also relates the majority to the political realm more directly by alleging that they seized legislative powers by declaring a law and further claims that the liberal Justices are the administration's tool for advancing its agenda. Consequently, it is argued that the Court's authority should be undermined by rejecting the ruling and pursuing a constitutional amendment through the legislative branch. What is striking about Fox News's Use of Power frame is that when the Court is presented as a tool against the administration, the frame is dominated by journalists and legal experts. By contrast, framing the Court as a tool of the administration is primarily done by the media and political contributors. Similarly, the media and political voices are the dominant contributors regarding the overall coverage of both channels, which aids perceiving the Court as just another political institution because the audience is likely to be familiar with the political pundits and guests from regular political reports. In the same manner, legal experts appear less frequently as to when the channels support the ruling. Besides, it is implied that the ruling does not comply with the whole corpus of American law. Moreover, the distance between the Court and the public is nartred by emphasizing the ruling's (negative) impact and, consequently, the decision becomes ultimately relevant to the audience. This finding is comparable to a previous study by Reference Missing for this xref r72Nicholson and Howard (2003) that found that the public questions the Supreme Court's legitimacy when the media augments the decision's consequences. Underlining the Court's similarities to political institutions further is done by conveying a sense of conflict by predominantly referring to it as fragmented into different groups and also by highlighting individual Justices. The important point is that while one channel supports a particular decision and presents its audience with reports that define the Court as different from political institutions, the other channel opposes the decision and, accordingly, frames the Court's practices as comparable to political procedures. As a consequence, audiences with contrary ideological beliefs are provided with different pieces of information and divergent evaluations of the Court, which can possibly lead to liberals and conservative having conflicting opinions about the Supreme Court. Hence, the previous two discussion points can be seen as a comparison that elaborates the differences between the channels' framing of the Supreme Court in the coverage of Hobby Lobby and Obergefell. It should be noted that these findings refer to the context of polarizing Supreme Court decisions that can be interpreted as either liberal or conservative. Although the findings only apply to that specific context, this does not weaken their significance as previous studies have pointed toward an over-reporting of decisions that deeply divided Court (Johnson \& Socker, 2008; Jones, 2014).

Fourth, it becomes clear that Fox News's programs convey a sense of fear and threat, whereas uncertainty and empathy are augmented on MSNBC. One possible explanation for why the channels create different atmospheres is that conservatives possibly identify with their ideology more strongly than 
liberals do and feel threatened when their values and beliefs are challenged. Consequently, Fox News responds by framing opposing views as a threat. In the same manner, Egan and Citrin (2011) found that conservatives' perception of the Court's legitimacy suffers after unpopular rulings, yet the reverse does not hold true for liberals. Hence, finding that Fox News reacts more strongly to opposing views seems reasonable. Besides, previous studies have shown that when confronted with information that runs contrary to their belief system, people will defend their views and sometimes even attack and deconstruct opposing ones (Davis, 2014). Presenting opposing views not only as unreasonable, but appealing to fear by framing them as a threat is extremely efficient to marginalize opposing beliefs, because rational thinking is bypassed and messages are more readily accepted when exposed to fear (Brader, 2005; Perloff, 2010). Moreover, Jamieson and Cappella (2008) found that one of the strategies used by Fox News to frame John Kerry as an inadequate presidential candidate was to evoke "strong negative [emotions]" (6) in the audience. Regarding Supreme Court Justices as part of the governmental body that exercises power over the American people, the present study's finding that Fox News conveys a sense of threat complies with Jamieson and Cappella's finding. In contrast to fear, MSNBC underlines the notions of uncertainty and empathy, which is done by mostly including contributors who are affected by the rulings. While feelings of uncertainty can also lead to fear, appealing to empathy fosters a sense of community and understanding, that is, "you are not alone." As Lakoff (2006) stated, the concept of community is essential to liberal ideology to achieve fulfillment in life. Moreover, the way in which the themes of empathy and uncertainty are emphasized is also resonates with liberal ideology. For instance, arguing that the Justices did not take the perspective of a disadvantaged group implies that they did not rule empathetically. Since empathy and equality are closely connected, not ruling empathetically fosters inequality.

\section{CONCLUSION}

Judicial tyranny or American justice? This question was the starting point for the present study and already indicated that the partisan news channels, Fox News and MSNBC, frame the U.S. Supreme Court in greatly different manners. The Supreme Court is dependent on high levels of public support in order to maintain its efficiency and legitimacy and if public support for the high Court sank dramatically, the Justices' integrity and impartiality could be impaired. Due to the Court's isolation from the public, the media has great control over the information the public bases its opinion about the Court on and, therefore, the media also affects how the public perceives the Court. It follows that the media's representation of the Supreme Court is of special interest. With regard to the steadily increasing polarization of political and ideological views and to the partisan divide in levels of support for the Supreme Court, partisan news channels are of great interest as they cater to informed and politically engaged audiences with distinct ideological beliefs. Yet, previous research has extensively focused on how the public perceives the Court as well as on how the media can affect public opinion toward the Court, whereas only a few studies explored how news outlets precisely frame the Supreme Court. To contribute to the small body of existing research and to fill the knowledge gap, the present study conducted a qualitative frame analysis of Fox News and MSNBC evening news transcripts. In particular, the news coverage of the decisions in Hobby Lobby and Obergefell was analyzed to reveal the differences in the channels' framing of the Court when the ruling does or does not comply with their ideological views and what strategies they use to reinforce their ideological beliefs.

In sum, the findings suggest that there is a correlation between how the Supreme Court is framed and whether the channel's ideological leaning is reflected by the Court's decision. Consequently, the Court is framed in a politicized manner when the decision does not reflect the channel's ideological beliefs, whereas the Court's distinctiveness from political institutions is emphasized when the decision complies with the channels' ideological views. Consequently, the findings indicate that partisan channels' coverage of polarizing decisions is asymmetrical and that their audiences are presented with greatly different information to base their evaluation of the judiciary on. This contrast is achieved through framing particular aspects of the Court, that is, by emphasizing and omitting specific pieces of information in order to encourage interpreting and evaluating the decision and the Court itself according to specific ideological preferences. Hence, the present study found that both channels appeal to distinct ideological values and frame their messages in a way that reinforces and strengthens these values. At the same time, however, conflicting views are opposed and marginalized. Hence, although both channels include opinions contrary to their own, it is argued that these are unreasonable as well as incompatible with the audience's views. Moreover, it should be noted that the Court is rather described as a divided institution than as an entity, whereby it is possible to further emphasize the ideological differences between the Justices. Besides, the findings suggest that it is mostly the media (i.e., the channel or other contributors from the journalistic field) that is involved in the framing of the Supreme Court. Hence, it can be seen as a link between the Supreme Court and the public, capable of affecting the relationship between the two.

The present study adds to the existing body of research on framing analysis, more specifically it adds to the knowledge of how partisan news outlets shape their narratives. Considering that the findings revealed that both partisan news channels reinforce their audiences' ideological beliefs by framing their reports accordingly, the present study confirms previous research on partisan news (Chalif, 2011; Jamieson \& Cappella, 2008; Levendusky, 2013a,b). Moreover, the findings can be related to LaRowe's (2010) study since both studies 
investigated how the Supreme Court is framed at different points in time. While LaRowe found that the Supreme Court is mostly presented as an apolitical, unified entity, the findings of the present study show that the Supreme Court is increasingly framed as a political institution. This implies that the partisan divide, once only common to the political realm, has now also reached the judicial branch. For one, previous studies have shown that politicization of the Court leads to low levels of public support (Hamilton, 2012). This can also be observed through survey data that reveals that public confidence in the Court is at its lowest point since 1976 (McCarthy, 2015), while perceiving the Court as politicized has steadily increased. As a consequence, the Court's legitimacy and independence are at risk, which are central to holding the balance between the three governmental branches and, consequently, fundamental for a sense of stability in the American government. Moreover, politicization of the Court also has consequences for the Supreme Court's appointment process as the political parties become more inclined to only consider nominees that reflect their beliefs. It should be noted again that the media exercises great control over the decision whether to frame the Court as an extension to the political branches, in that the Justices base their rulings on the party affiliation of the President that nominated them, or to present their decisions as interpretations of the law and make them comprehensible to the public.

However, certain limitations have to be taken into consideration when evaluating the findings. On the one hand, it can be argued that qualitative research methods are inevitably subjective, at least to some extent. This issue was addressed by a great degree of transparency that provides insight into the research process. On the other hand, the analyzed sample is highly specialized and includes only a small number of transcripts, which means that findings resulting from the analysis cannot be generalized. Nevertheless, the present study provides knowledge about how the Supreme Court is presented in partisan news and, on a more general level, about how these news channels utilize framing to present reports in order to reinforce their audiences' ideological beliefs. Apart from analyzing bigger samples, it would be interesting for future research to explore how left-leaning news outlets frame the Court during a Republican presidency in order to compare if these outlets respond in the same way as Fox News did in covering Hobby Lobby and Obergefell, that is, if liberal outlets frame the Court as a tool used against or by the administration as well. Besides, future studies could compare how partisan news' framing of the Court differs from more centered news outlets' framing, which might present rather neutral reports that possibly include elements from both sides of the debate. Finally, future research could investigate a greater timeframe in order to see how the media's framing of the Court has changed over the years. Although LaRowe's (2010) study analyzed newspaper articles on the Supreme Court from 1997 to 2004, however it would be interesting to see how television news framed the Court prior the advent of partisan channels, that is, early 1990s. Similarly, in order to further investigate the increasing politicization of the Court, studies could focus on the past 10 years considering that the partisan divide has expanded remarkably during that time.

Finally, it can be said that framing the U.S. Supreme Court as a symbol for judicial tyranny or American justice seems to be dependent on whether the Court's decision reflects the partisan channels' ideological beliefs. Thus, the audiences of partisan channels are presented two vastly different narratives of the same decision, each reinforcing their views and objecting to opposing ones.

\section{References}

Aday, S. (2010). Chasing the bad news: An analysis of 2005 Iraq and Afghanistan war coverage on NBC and Fox News channel. Journal of Communication, 60(1), 144-164. doi:10.1111/j.1460-2466. 2009.01472.x

Aday, S., Livingston, S., \& Hebert, M. (2005). Embedding the truth a cross-cultural analysis of objectivity and television coverage of the Iraq War. The Harvard International Journal of Press/Politics, 10(1), 3-21. doi:10.1177/1081180X05275727

Anderson, J. N. (2008). Framing same-sex marriage: An analysis of 2004 newspaper coverage of marriage legislation. Dissertation. Miami University. Retrieved March 20, 2016, from http://rave. ohiolink.edu/etdc/view?acc_num=miami1215012253

Arceneaux, K., \& Johnson, M. (2013). Changing minds or changing channels?: Partisan news in an age of choice. Chicago, IL: University of Chicago Press.

Bai, M. (2009, December 2). Cable Guise. The New York Times. Retrieved June 12, from http://www.nytimes.com/2009/12/06/ magazine/06fob-wwln-t.html

Baier, B. (2015, June 26). “One escaped convict killed." Fox Special Report with Bret Baier. Fox News Network. Transcript. LexisNexis Academic.

Baird, V. A., \& Gangl, A. (2006). Shattering the myth of legality: The impact of the media's framing of Supreme Court procedures on perceptions of fairness. Political Psychology, 27(4), 597-614. doi:10.1111/j.1467-9221.2006.00518.x

Bartels, B. L., \& Johnston, C. D. (2013). On the ideological foundations of Supreme Court legitimacy in the American public. American Journal of Political Science, 57(1), 184-199. doi:10.1111/j.15405907.2012.00616.x

Baum, M. A. (2012). Preaching to the choir or converting the flock: Presidential communication strategies in the age of three Medias. In R. L. Fox \& J. M. Ramos (Eds.), iPolitics: Citizens, elections, and governing in the new media era (pp. 286-311). New York: Cambridge University Press.

Brader, T. (2005). Striking a responsive chord: How political ads motivate and persuade voters by appealing to emotions. American Journal of Political Science, 49(2), 388-405. doi:10.1111/j.00925853.2005.00130.x

Bream, S. (2014, June 30). Supreme Court rules against administration. Fox Special Report with Bret Baier. Fox News Network. Transcript. LexisNexis Academic.

Burwell v. Hobby Lobby Stores, Inc., 573 U.S. _ (2014).

Carlin, D. B., \& Winfrey, K. L. (2009). Have you come a long way, baby? Hillary Clinton, Sarah Palin, and Sexism in 2008 campaign coverage. Communication Studies, 60(4), 326-343. doi:10.1080/ 10510970903109904 
Chalif, R. S. (2011). Selective politics: The fragmentation and polarization of news on cable TV. Dissertation, Georgetown University. Retrieved March 5, 2016, from http://hdl.handle.net/10822/ 552906

Davis, R. (2014). The symbiotic relationship between the U.S. Supreme Court and the Press. In R. Davis (Ed.), Covering the United States Supreme Court in the digital age (pp. 4-23). New York: Cambridge University Press.

De Vreese, C. H. (2005). News framing: Theory and typology. Information Design Journal + Document Design, 13(1), 51-62. Retrieved April 1, 2016, from http://msap-unlam.ac.id/download/bahan_ bacaan/New\%20Framing.pdf

Ditto, P. H., \& Lopez, D. F. (1992). Motivated skepticism: Use of differential decision criteria for preferred and nonpreferred conclusions. Journal of Personality and Social Psychology, 63(4), 568-584. doi:10.1037/0022-3514.63.4.568

Drake, B. (2016, February 17). 5 facts about the Supreme Court. Pew Research Center. Retrieved June 13, 2016, from http://www. pewresearch.org/fact-tank/2016/02/17/5-facts-about-the-supremecourt/

Eagleton, T. (1991). Ideology: An introduction. New York: Verso.

Egan, P. J., \& Citrin, P. (2009). Opinion Leadership, Backlash, and Delegitimation: Supreme Court Rulings and Public Opinion. Retrieved May 5, 2016, from http://ssrn.com/abstract=1443631

Egan, P. J., \& Citrin, J. (2011). The limits of judicial persuasion and the fragility of judicial legitimacy. Working Papers. Retrieved April 1, 2016, from http://escholarship.org/uc/item/2gh262w3

Entman, R. M. (1993). Framing: Toward clarification of a fractured paradigm. Journal of Communication, 43(4), 51-58. doi:10.1111/ j.1460-2466.1993.tb01304.x

Entman, R. M. (2003). Cascading activation: Contesting the White House's frame after 9/11. Political Communication, 20(4), 415432. doi:10.1080/10584600390244176

Entman, R. (2007). Framing Bias: Media in the Distribution of Power Journal of Communication, 57(1), 163-173. doi:10.1111/j.14602466.2006.00336.x

Entman, R. M. (2010). Media framing biases and political power: Explaining slant in news of campaign 2008. Journalism, 11(4), 389-408. doi:10.1177/1464884910367587

Feldman, L., Maibach, E. W., Roser-Renouf, C., \& Leisetritz, A. (2011). Climate on cable: The nature and impact of global warming coverage on Fox News, CNN, and MSNBC. The International Journal of Press/Politics, 17(1), 3-31. doi:10.1177/1940161211425410

Fiske, S. T., \& Taylor, S. E. (1991). Social Cognition. (2nd ed.). New York: McGraw-Hill.

Gamson, W. A. (1992). Talking politics. Cambridge: Cambridge University Press.

Gibson, J. L., \& Caldeira, G. A. (2003). The Supreme Court and the US Presidential Election of 2000: Wounds, Self-Inflicted or Otherwise? British Journal of Political Science, 33(4), 535-556. doi:10.1017/S0007123403000243

Gibson, J. L., \& Caldeira, G. A. (2009). Confirmation politics and the legitimacy of the US Supreme Court: Institutional loyalty, positivity bias, and the Alito nomination. American Journal of Political Science, 53(1), 139-155. doi:10.1111/j.1540-5907.2008. 00362.x

Gibson, J. L., Lodge, M., Taber, C., \& Woodson, B. (2010). Can Judicial Symbols Produce Persuasion and Acquiescence? Testing a MicroLevel Model of the Effects of Court Legitimacy. Paper presented at the Midwest Political Science Association. Chicago, IL, April 21-24, 2010. http://www.academia.edu/25485648/Can_Judicial_Symbols_ Produce_Persuasion_and_Acquiescence_Testing_a_Micro-Level_Model_ of_the_Effects_of_Court_Legitimacy
Gibson, J. L., \& Caldeira, G. A. (2011). Has legal realism damaged the legitimacy of the US Supreme Court? Law \& Society Review, 45(1), 195-219. doi:10.1111/j.1540-5893.2011.00432.x

Gibson, J. L., \& Nelson, M. (2014). Change in institutional support for the US Supreme Court: Is the Court's legitimacy imperiled by the decisions it makes? SSRN Journal. Retrieved April 3, 2016, from http://ssrn.com/abstract=2466422

Gibson, J. L., Caldeira, G. A., \& Spence, L. K. (2003). The Supreme Court and the US presidential election of 2000: Wounds, self-inflicted or otherwise? British Journal of Political Science, 33(4), 535-556. doi:10.1017/S0007123403000243

Gibson, J. L., Lodge, M., \& Woodson, B. (2014). Legitimacy, losing, but accepting: A test of positivity theory and the effects of judicial symbols. SSRN Journal. Retrieved from http://ssrn.com/abstract= 2448710

Goffman, E. (1974). Frame analysis. New York: Harper \& Row.

Hamilton, E. (2012). Politicizing the Supreme Court. Stanford Law Review Online, 65(35), 35-40. Retrieved March 3, 2016, from https://www.stanfordlawreview.org/online/politicizing-supremecourt

Handley, R. L. (2010). Cascading activation: Bush's 'War on Terrorism' and the Israeli-Palestinian conflict. Journalism, 11(4), 445-461. doi:10.1177/1464884910367595

Hannity, S. (2014, June 30). Supreme Court rules in favor of Hobby Lobby. Fox Hannity. Fox News Network. Transcript. LexisNexis Academic.

Hayes, C. (2014, June 30). All in with Chris Hayes. MSNBC. Transcript. LexisNexis Academic.

Hayes, C. (2015, June 26). All in with Chris Hayes. MSNBC. Transcript. LexisNexis Academic.

Holbert, R. L., Garrett, R. K., \& Gleason, L. S. (2010). A new era of minimal effects? A response to Bennett and Iyengar. Journal of Communication, 60(1), 15-34. doi:10.1111/j.1460-2466.2009.01470.x

Holcomb, J. (2016, June 15). Cable news: Fact sheet. Pew Research Center. Retrieved June 20, 2016, from http://www.journalism. org/2016/06/15/cable-news-fact-sheet/

Hollander, B. A. (2008). Tuning out or tuning elsewhere? Partisanship, polarization, and media migration from 1998 to 2006. Journalism \& Mass Communication Quarterly, 85(1), 23-40. doi:10.1177/ 107769900808500103

Hollingsworth v. Perry, 570 U.S. _ (2013).

Hyde Amendment Codification Act. S 142, 113th Cong. (2013).

How Americans Get Their News. (2014, March 17). American Press Institute. Retrieved January 10, 2016, from https://www.americanpressinstitute.org/publications/reports/survey-research/howamericans-get-news/

Ideological Placement of Each Source's Audience. (2014, October 20). Pew Research Center. Retrieved December 10, 2015, from http:// www.journalism.org/2014/10/21/political-polarization-mediahabits/pj_14-10-21_mediapolarization-08/

Jamieson, K. H., \& Cappella, J. N. (2008). Echo Chamber: Rush Limbaugh and the conservative media establishment. New York: Oxford University Press.

Johnson, T. (2014). How and why the Supreme Court remains undercovered. In R. Davis (Ed.), Covering the United States Supreme Court in the digital age (pp. 23-42). New York: Cambridge University Press.

Johnson, T., \& Socker, E. (2008). Media coverage and public opinion of the Supreme Court. Annual Meeting of the Midwest Political Science Association. Chicago, IL.

Jones, J. M. (2015, July 16). Republicans' approval of Supreme Court sinks to 18\%. Gallup. Retrieved March 10, 2016, from http:// www.gallup.com/poll/184160/republicans-approval-supremecourt-sinks.aspx 
Jones, R. A. (2014). Media politicization of the United States Supreme Court. Oñati Socio-Legal Series, 4(4). Retrieved April 5, 2016, from http://ssrn.com/abstract $=2499231$

Jurkowitz, M., Hitlin, P., Mitchell, A., Santhanam, L., Adams, S., Anderson, M., et al. (2013). The changing TV news landscape. Pew Research Center. Retrieved February 10, 2016, from http://www. stateofthemedia.org/2013/special-reports-landing-page/the-changingtv-news-landscape/

Kelly, M. (2014, June 30). Interview with Bill Ayers. The Kelly File. Fox News Network. Transcript. LexisNexis Academic.

Kelly, M. (2015, June 26). Supreme Court: Same-sex marriage legal. The Kelly File. Fox News Network. Transcript. LexisNexis Academic.

Kiley, J. (2014, July 31). Americans divided on how the Supreme Court should interpret the constitution. Pew Research Center. Retrieved June 15, 2016 from http://www.pewresearch.org/fact-tank/ 2014/07/31/americans-divided-on-how-the-supreme-court-shouldinterpret-the-constitution/

Kuypers, J. A. (2010). Framing analysis from a rhetorical perspective. In P. D'Angelo \& J. A. Kuypers (Eds.), Doing news framing analysis: Empirical and theoretical perspectives (pp. 286-311). New York: Taylor \& Francis.

Lakoff, G. (2006). Thinking points: Communicating our American values and vision. New York: Farrar, Straus and Giroux.

LaRowe, N. (2010). On and off the Supreme Court beat: A content analysis of newspaper coverage of the Supreme Court from 19972004. APSA 2010 Annual Meeting Paper. Washington, DC: September 2-5, 2010.

Levendusky, M. S. (2013a). Why do partisan media polarize viewers? American Journal of Political Science, 57(3), 611-623. doi:10. 1111/ajps.12008

Levendusky, M. S. (2013b). Partisan media exposure and attitudes toward the opposition. Political Communication, 30(4), 565-581. doi:10.1080/10584609.2012.737435

Loving v. Virginia, 388 U.S. 1 (1967).

Luberda, R. (2008). The fourth branch of the government: Evaluating the media's role in overseeing the independent judiciary. Notre Dame Journal of Law, Ethics \& Public Policy, 22(2), 507-532. Retrieved March 12, 2016, from http://scholarship.law.nd.edu/ ndjlepp/vol22/iss2/11

Maddow, R. (2014, June 30). The Rachel Maddow Show. MSNBC. Transcript. LexisNexis Academic.

Maddow, R. (2015, June 26). The Rachel Maddow Show. MSNBC. Transcript. LexisNexis Academic.

Matsa, K. E. (2016, June 15). Network news: Fact sheet. Pew Research Center. Retrieved June 20, 2016, from http://www.journalism. org/2016/06/15/network-news-fact-sheet/

Maxwell, J. (1992). Understanding and validity in qualitative research. Harvard Educational Review, 62(3), 279-301. http://dx/doi/org/ 10.17763/haer.62.3.8323320856251826

McCarthy, J. (2015). Disapproval of Supreme Court edges to new high. Gallup. Retrieved June 20, 2016, from http://www.gallup.com/ poll/185972/disapproval-supreme-court-edges-new-high.aspx

McCullen v. Coakley, 573 U.S. _ (2014).

Morris, J. S. (2007). Slanted objectivity? Perceived media bias, cable news exposure, and political attitudes. Social Science Quarterly, 88(3), 707-728. http://dx/doi/org/10.1111/j.1540-6237.2007.00479.x

Morris, J. S., \& Francia, P. L. (2010). Cable news, public opinion, and the 2004 party conventions. Political Research Quarterly, 63(4), 834-849. http://dx/doi/org/10.1177/1065912909338463

Mutz, D. C. (2006). How the mass media divide us. In P. S. Nivola \& D. W. Brady (Eds.), Red and blue nation? Characteristics and causes of America's polarized politics (pp. 223-248). Washington, DC: Brookings Institution Press.
Nicholson, S. P., \& Howard, R. M. (2003). Framing support for the Supreme Court in the aftermath of Bush v. Gore. Journal of Politics, 65(3), 676-695. doi:10.1111/1468-2508.00207

Obbie, M. (2007). Winners and losers. In K. J. Bybee (Ed.), Bench press: The collision of courts, politics, and the media (pp. 153-176). Stanford, CA: Stanford University Press.

Obergefell v. Hodges, 576 U.S. _ (2015).

O'Donnell, L. (2014, June 30). The Last Word with Lawrence O'Donnell. MSNBC. Transcript. LexisNexis Academic.

Olmstead, K., Mark, J., Amy, M., \& Enda, J. (2013). How Americans get TV news at home. Pew Research Center. Retrieved March 10, 2016, from http://www.journalism.org/2013/10/11/how-americansget-tv-news-at-home/

O'Reilly, B. (2014, June 30). Traditional Americans win big. The O'Reilly Factor. Fox News Network. Transcript. LexisNexis Academic.

Pan, P.-L., Meng, J., \& Zhou, S. (2010). Morality or equality? Ideological framing in news goverage of gay marriage legitimization. The Social Science Journal, 47(3), 630-645. doi:10.1016/j.soscij.2010.02.002

Perloff, R. M. 2010. Message factors (4th ed.). In R. M. Perloff (Ed.), The dynamics of persuasion: Communication and attitudes in the twenty-first century (pp. 184-224). New York: Routledge.

Political Polarization in the American Public. (2014, June 12). Pew Research Center. Retrieved June 26, 2016 from http://www. people-press.org/2014/06/12/political-polarization-in-the-americanpublic/

Prior, M. (2005). News vs. entertainment: How increasing media choice widens gaps in political knowledge and turnout. American Journal of Political Science, 49(3), 577-592. doi:10.2307/3647733

Prior, M. (2007). Post-broadcast democracy: How media choice increases inequality in political involvement and polarizes elections. New York: Cambridge University Press.

Prior, M. (2013). Media and Political Polarization. Annual Review of Political Science, 16, 101-127. Retrieved May 25, 2016, from http://ssrn.com/abstract=2265184

Ramirez, M. D. (2008). Procedural perceptions and support for the US Supreme Court. Political Psychology, 29(5), 675-698. doi:10. 1111/j.1467-9221.2008.00660.x

Religious Freedom Restoration Act of 1993. Pub. L. No. 101-336, §3, 107 Stat. 1488 (1993).

Rosen, J. (2007, January/February). Roberts's rules. The Atlantic. Retrieved May 8, 2016, from http://www.theatlantic.com/magazine/archive/ 2007/01/robertss-rules/305559/

Scheb, J. M., II. \& Lyons, W. (2001). Judicial behavior and public opinion: Popular expectations regarding the factors that influence Supreme Court decisions. Political Behavior, 23(2), 181-194. doi:10. 1023/A:1013037915485

Semetko, H. A., \& Valkenburg, P. M. (2000). Framing European politics: A content analysis of press and television news. Journal of Communication, 50(2), 93-109. doi:10.1111/j.1460-2466.2000.tb02843.x

Sharpton, Al. (2014, June 30). Politics Nation. MSNBC. Transcript. LexisNexis Academic.

Smith, G., \& Searles, K. (2012). Fair and balanced news or a difference of opinion? Why opinion shows matter for media effects. Political Research Quarterly, 1-14. doi:10.1177/1065912912465922

Smith, G., \& Searles, K. (2014). Who let the (attack) dogs out? New evidence for partisan media effects. Public Opinion Quarterly, 78(1), 71-99. doi:10.1093/poq/nft082

Strauss, A., \& Corbin, J. (1998). Basics of qualitative research: Techniques and procedures for developing grounded theory (2nd ed.). Thousand Oaks, CA: Sage.

Stroud, N. J. (2007). Media effects, selective exposure, and Fahrenheit 9/11. Political Communication, 24(4), 415-432. doi:10.1080/ 10584600701641565 
Stroud, N. J. (2008). Media use and political predispositions: Revisiting the concept of selective exposure. Political Behavior, 30(3), 341366. doi:10.1007/s11109-007-9050-9

Stroud, N. J. (2010). Polarization and partisan selective exposure. Journal of Communication, 60(3), 556-576. doi:10.1111/j.14602466.2010.01497.x

Sunstein, C. R. (2001). Republic. Com. Princeton, NJ: Princeton University Press.

Sunstein, C. R. (2009a). Going to extremes: How like minds unite and divide. New York: Oxford University Press.

Sunstein, C. R. (2009b). Republic. Com 2.0. Princeton, NJ: Princeton University Press.

Taber, C. S., Cann, D., \& Kucsova, S. (2008). The motivated processing of political arguments. Political Behavior, 31(2), 137-155. doi: 10.1007/s11109-008-9075-8

Taber, C. S., \& Lodge, M. (2006). Motivated skepticism in the evaluation of political beliefs. American Journal of Political Science, 50(3), 755-769. doi:10.1111/j.1540-5907.2006.00214.x

United States v. Windsor, 570 U.S. _ (2013).

U.S. Constitution. Art. II, Sect. 2.

Van Gorp, B. (2010). Strategies to take subjectivity out of framing analysis. In J. A. Kuypers \& P. D'Angelo (Eds.), Doing news framing analysis: Empirical and theoretical perspectives, (pp. 84-109). New York: Taylor \& Francis.

Van Gorp, B., \& Vercruysse, T. (2012). Frames and counter-frames giving meaning to dementia: A framing analysis of media content. Social Science \& Medicine, 74(8), 1274-1281. doi:10.1016/ j.socscimed.2011.12.045

Van Leuven, N. (2006). Cascades of news framing: Wrangling rhetoric in Schwarzenegger's "The Indians Are Ripping Us Off." Annual Meeting of the International Communication Association. Retrieved April 7, 2016, from http://citation.allacademic.com//meta/p_mla_ apa_research_citation/0/9/1/0/5/pages91051/p91051-1.php

Van Susteren, G. (2014, June 30). Supreme Court rules in favor of Hobby Lobby. Fox on the Record with Greta van Susteren. Fox News Network. Transcript. LexisNexis Academic.

Where Fox News's Audience Fits on the Political Spectrum. (2014, October 21). Pew Research Center. Retrieved December 10, 2015, from http://www.journalism.org/interactives/media-polarization/ outlet/fox-news/
Where MSNBC's Audience Fits on the Political Spectrum. (2014, October 21). Pew Research Center, October 21. Retrieved December 10, 2015, from http://www.journalism.org/interactives/ media-polarization/outlet/msnbc/

Winkler, A. (2006). Fatal in theory and strict in fact: An empirical analysis of strict scrutiny in the federal courts. Vanderbilt Law Review, 59, 793-871. Retrieved March 2, 2016, from http://ssrn. com/abstract $=897360$

Yuhas, A., \& Helmore, E. (2016, March 20). Republican opposition to Supreme Court nominee 'showing cracks', says Reid. The Guardian. Retrieved June 15, 2016, from http://www.theguardian.com/ law/2016/mar/20/republicans-opposition-supreme-court-nomineemerrick-garland

\section{Competing Interests}

The authors declare no competing interests.

\section{PUBLISHING NOTES}

(C) 2016 L. Matthias. This work has been published open access under Creative Commons Attribution License CC BY 4.0, which permits unrestricted use, distribution, and reproduction in any medium, provided the original work is properly cited. Conditions, terms of use and publishing policy can be found at www.scienceopen.com.

Please note that this article may not have been peer reviewed yet and is under continuous post-publication peer review. For the current reviewing status please click here or scan the QR code on the right.

\section{scienceOPEN.com}




\section{APPENDIX: FRAMING PROCESS}

Fox News \& Hobby Lobby

Open Coding: Check on Power, Compliance with Law, Consequences, Dissent, Fairness, Independence, Judges' Leaning, Legal Principles, Political Influence, Protection by Supreme Court, Strict Scrutiny, Threat, War on Women

Axial Coding: Process, Use of Power, Dissenters

Selective Coding:

\begin{tabular}{llll}
\hline & Process & Use of Power & Dissenters \\
\hline Problem & $\begin{array}{l}\text { Not problematic } \\
\text { because ruling } \\
\text { based on RFRA, } \\
\text { nartrly tailored, } \\
\text { burden lifted }\end{array}$ & $\begin{array}{l}\text { Fulfills } \\
\text { institutional } \\
\text { function, } \\
\text { counterweight } \\
\text { to Obama }\end{array}$ & $\begin{array}{l}\text { Dissenters: } \\
\text { women's rights } \\
\text { more important } \\
\text { than religious } \\
\text { freedom, want } \\
\text { taxpayers to fund } \\
\text { abortions } \\
\text { Different } \\
\text { ideologies, political } \\
\text { motifs }\end{array}$ \\
Evaluse & Majority & Supreme Court & Scary, disturbing \\
Evaluation & $\begin{array}{l}\text { Good, fair, } \\
\text { constitutional }\end{array}$ & $\begin{array}{l}\text { Strong, } \\
\text { prepared, } \\
\text { willing, } \\
\text { protective }\end{array}$ & \\
& & Appoint no more \\
Remedy & & & liberal Justice \\
\hline
\end{tabular}

MSNBC \& Obergefell v. Hodges

Open Coding: Authority, Compliance with Law, Counterframe, Equality, Judicial Temperament Legal Principles, Opposition, Precedent, Procedure, Ruling Final, Supreme Court Function

Axial Coding: Process, Opposition

Selective Coding:

\begin{tabular}{lll}
\hline & Process & Opposition \\
\hline Problem & $\begin{array}{l}\text { Not problematic because ruling is } \\
\text { based on legal principles and } \\
\text { precedent, discrimination } \\
\text { unconstitutional }\end{array}$ & $\begin{array}{l}\text { Opposition questions } \\
\text { ruling's constitutionality }\end{array}$ \\
Cause & $\begin{array}{l}\text { Supreme Court (especially } \\
\text { majority) }\end{array}$ & Judicial restraint \\
Evaluation & $\begin{array}{l}\text { Justice, right, fair } \\
\text { Remedy }\end{array}$ & $\begin{array}{l}\text { Weird, unusual } \\
\text { needed }\end{array}$ \\
\hline
\end{tabular}

Fox News \& Obergefell v. Hodges

Open Coding: Democratic Process, Exceeding Authority, Justices' Leaning, Impact, Invention, Political Influence, Threat

Axial Coding: Process, Use of Power

Selective Coding:

\begin{tabular}{|c|c|c|}
\hline & Process & Use of Power \\
\hline Problem & $\begin{array}{l}\text { Process flawed because right } \\
\text { to equal dignity does not } \\
\text { exist, act of will not of legal } \\
\text { judgment }\end{array}$ & $\begin{array}{l}\text { Abuse of power, exceeding } \\
\text { jurisdiction, take on } \\
\text { legislative function }\end{array}$ \\
\hline Cause & Majority (especially Kennedy) & Majority \\
\hline Evaluation & Threat, political ruling & $\begin{array}{l}\text { Trepidation, tyranny, } \\
\text { imperial Court }\end{array}$ \\
\hline Remedy & $\begin{array}{l}\text { Base decisions on Founding } \\
\text { Fathers' intent }\end{array}$ & $\begin{array}{l}\text { Legislative issues should be } \\
\text { solved by legislature }\end{array}$ \\
\hline
\end{tabular}

\section{MSNBC \& Hobby Lobby}

Open Coding: Ambiguity, Court \& Politics, Inconsistency, Inequality, Interfering with Law, Legal Principles, Majority Being Unclear, No Empathy, No Explanation, Other Religions

Axial Coding: Process, Legal Abilities

Selective Coding:

\begin{tabular}{|c|c|c|}
\hline & Process & Legal Abilities \\
\hline Problem & $\begin{array}{l}\text { Process problematic because } \\
\text { ruling does not comply with } \\
\text { entire corpus of law, } \\
\text { procedural fairness questioned, } \\
\text { wrong understanding of } \\
\text { religious freedom }\end{array}$ & $\begin{array}{l}\text { Court characterized by } \\
\text { uncertainty, inequality, } \\
\text { political motifs }\end{array}$ \\
\hline Cause & Majority & Supreme Court \\
\hline Evaluation & Weird, poor judgment & $\begin{array}{l}\text { Disappointing, not } \\
\text { surprising, mind-boggling }\end{array}$ \\
\hline Remedy & & Ethics code for Justices \\
\hline
\end{tabular}

